\title{
Análise Morfométrica e Morfológica da Ilha da Trindade, Atlântico Sul, Brasil
}

\author{
Morphometric and Morphological Analysis of Trindade Island, South \\ Atlantic, Brazil
}

\section{Gabriel Silva Nogueira ${ }^{1}$ Julia Frederica Effgen ${ }^{2}$ Eberval Marchioro ${ }^{3}$}

\author{
Palavras-chave \\ Ilhas oceânicas \\ Hidrologia \\ Índice Topográfico de Umidade \\ Geomorphons
}

\begin{abstract}
Resumo
Apesar de bem estabelecida em bacias hidrográficas continentais, a análise morfométrica ainda é pouco desenvolvida em ilhas oceânicas. Este trabalho tem como objetivo analisar a morfometria e classificar morfologicamente a ilha da Trindade, localizada no Atlântico Sul e, verificar sua relação com o ITU. Foram utilizados os parâmetros de altimetria, declividade, fator LS, Índice Topográfico de Umidade (ITU) e a classificação Geomorphons. A ilha da Trindade tem amplitude altimétrica de $600 \mathrm{~m}$, sendo que $34 \%$ da área da ilha tem cota entre $0-100 \mathrm{~m}$ e, $21,2 \%$ tem entre $100-200 \mathrm{~m}$. As áreas mais baixas da ilha são praias de cascalho, areia e leques aluviais. Divisores de água como os picos do Desejado e Verde correspondem às porções acima de $500 \mathrm{~m}$ e ocupam cerca de $2 \%$ da área da ilha. A declividade varia de fortemente ondulada (20-45\%) a montanhosa (45-75\%), com ambas as classes ocupando mais de metade da ilha. As porções mais aplainadas (declividade entre 0-3\% e 3-8\%) ocupam menos de $4 \%$ da área. Verifica-se que as faces das vertentes mais expostas da ilha às intempéries climáticas (vento e chuva) são as orientadas a leste e sudeste e, portanto, são as mais trabalhadas por processos escultores do relevo. As faces oeste e noroeste são as mais escarpadas e protegidas das ações de intempéries climáticas. A classificação por Geomorphons mostrou que $57 \%$ da área da ilha é composta por encostas retilíneas, $19 \%$ são cristas secundárias (encostas levemente convexas em plano e perfil) e 18,6\% são concavidades. O ITU aponta para setores com tendência a saturação em concavidades do relevo e terços médios e inferiores das encostas, com predominância na porção leste.
\end{abstract}

\footnotetext{
${ }^{1}$ Departamento de Geografia/Programa de Pós-Graduação em Geografia (UFES). Laboratório de Monitoramento e Modelagem de Sistemas Ambientais (Lamosa). E-mail: gbl.snog@gmail.com

${ }^{2}$ Departamento de Geografia/Programa de Pós-Graduação em Geografia (UFES). Laboratório de Monitoramento e Modelagem de Sistemas Ambientais (Lamosa). E-mail: juliaeffgen@gmail.com

${ }^{3}$ Departamento de Geografia/Programa de Pós-Graduação em Geografia (UFES). Laboratório de Monitoramento e Modelagem de Sistemas Ambientais (Lamosa). E-mail: ebervalm@gmail.com
} 


\section{Keywords}

Oceanic Islands

Hydrology

Wetness Topographic Index

Geomorphons

\begin{abstract}
Although being well established in continental watersheds, morphometric analysis is still incipient in oceanic islands. This paper aims to analyze the morphometry and morphologically classify the Trindade Isle, in South Atlantic. The parameters used were altitude, slope gradient, LS factor, Topographic Wetness Index (WTI) and Geomorphons classification. Trindade isle has an altimetric amplitude of $600 \mathrm{~m}$, with $34 \%$ of its area between $0-100 \mathrm{~m}$ and $21.2 \%$ in the $100-200 \mathrm{~m}$ class. The isle's lower parts are gravel and sand beaches and alluvial fans. Ridgelines such as the Desejado and Verde peaks represent heights above $500 \mathrm{~m}$ and occupy $2 \%$ of the isle's area. Slope gradients vary from strongly undulated (20-45\%) to hilly (45-75\%), with both classes occupying half the isle's area. Flatter areas (with slope gradients between $0-3 \%$ and 3-8\%) occupy less than $4 \%$ of the isle. The slope faces more exposed to weather conditions (rainfall and winds) are the oriented to east and southeast, therefore being the most prone to modelling relief processes. The western and northwestern faces are steeper and more sheltered. The Geomorphons classification has shown that $57 \%$ of the isle is composed by straight slopes, $19 \%$ are spurs (slightly convex slopes in plan and profile), and $18.6 \%$ are hollows. The WTI shows that the areas prone to saturation are relief concavities and in the medium to lower thirds of the slopes.
\end{abstract}

\section{INTRODUÇÃO}

Desde o trabalho pioneiro de Robert E. Horton de 1945, a análise morfométrica tem se constituído em uma importante ferramenta de análise do relevo. A partir da década de cinquenta, novos parâmetros foram apresentados por Sthraler (1952; 1957), buscando melhorar ou inserir novas variáveis para a análise morfométrica e morfológica do relevo. No Brasil, foram desenvolvidos pioneiramente por Christofoletti (1969).

Desde então, a análise quantitativa e da morfologia, de suas inter-relações entre a fisiografia e a dinâmica evolutiva do relevo, passaram a ser palco de estudos de caráter geográfico.

Em termos temporais, depois do trabalho pioneiro de Christofoletti (1969), outros foram desenvolvidos por diversos autores com objetivos distintos, tais como de avaliação e análises de bacias hidrográficas (TORRES et al., 2011; MOURA, 2013; SPANGHERO; MELIANI; MENDES, 2015; FERNANDEZ, 2016), como subsidio para zoneamento territorial e também sustentabilidade ambiental (SANTOS; SOBREIRA, 2008; CLEMENTE et al., 2011; UMETSU et al., 2012), como caracterização e análise morfométrica (BARROS; STEINKE, 2009; STIPP et al., 2010; CARVALHO et al., 2014).

Mas de maneira geral, esses trabalhos foram desenvolvidos prioritariamente em bacias hidrográficas de áreas continentais, sendo ainda incipientes em ilhas oceânicas de origem vulcânicas, tal como a Ilha da Trindade, na região do Atlântico Sul. Nesse sentido, este trabalho visa analisar morfometricamente e morfologicamente a ilha da Trindade, bem como verificar sua relação 
com o índice topográfico de umidade.

\section{ÁREA DE ESTUDOS}

A ilha da Trindade está localizada entre os paralelos $20^{\circ} 29^{\prime} \mathrm{S}$ e $20^{\circ} 32^{\prime} \mathrm{S}$ e os meridianos $29^{\circ} 21^{\prime} \mathrm{W}$ e $29^{\circ} 17^{\prime} \mathrm{W}$, a $1140 \mathrm{~km}$ da cidade de Vitória - ES e 1870km de Fernando de Noronha-PE, Figura 1.

Conforme dispõe o Art. 20, inciso IV, da Constituição Federal, é um bem da União, entregue pela Secretaria do Patrimônio da União (SPU) ao encargo da Marinha do Brasil (MB), que vem sendo desde 1957 ocupada por militares da Marinha do Brasil no Posto Oceanográfico da Ilha da Trindade (POIT).

$\mathrm{Na}$ ilha, encontram-se rios perenes e temporários (Erro! Fonte de referência não encontrada.) favorecendo estudos geológicos, geomorfológicos, biológicos, oceanográficos e hidrossedimentológicos.

Devido ao isolamento geográfico,
Trindade apresenta elevada concentração de espécies endêmicas e ameaçadas de extinção. As características únicas da área atraem as atenções de cientistas desde o século XIX, incluindo trabalhos realizados por Charles Darwin a bordo do navio HMS Beagle, em 1832 (MURPHY, 1915).

Estudos como este, contribuem para subsidiar a criação de plano de manejo, que de acordo com a legislação pertinente deve acontecer em até cinco anos após a criação das unidades de conservação (UCs). Tendo em vista, que através do Decreto ${ }^{\circ} 9.312$ de 19 de março de 2018, foi criada a Área de Proteção Ambiental - APA da Ilha da Trindade e o Monumento Natural da Ilha da Trindade, com finalidade de preservar I - remanescentes do ecossistema insular do domínio da Mata Atlântica; II - belezas cênicas; e III - recursos naturais e biodiversidade marinhos na parte da cadeia submersa (BRASIL, 2018).

Figura 1 - Localização da Ilha da Trindade, Brasil, Atlântico Sul, ocupada permanentemente desde 1957. 


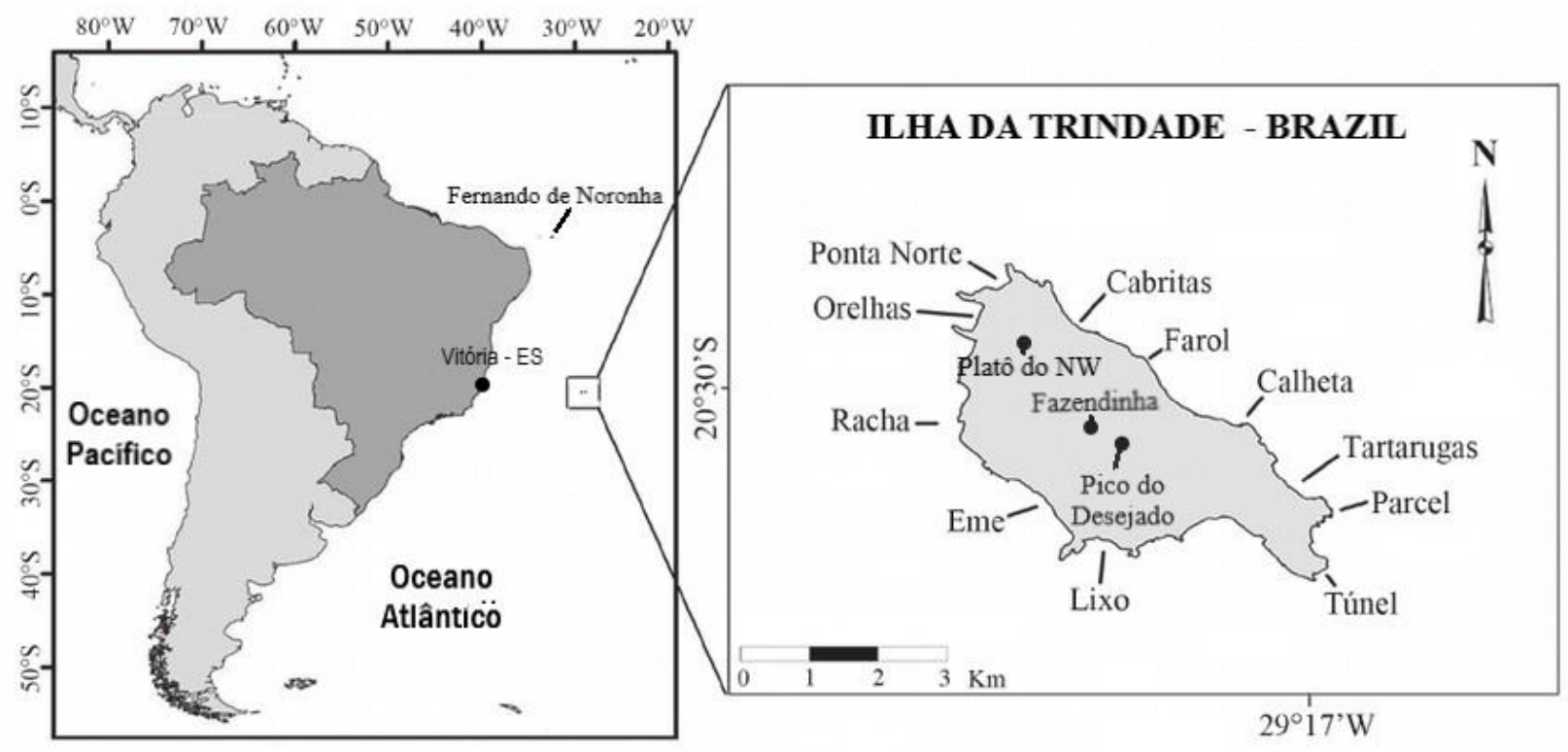

Fonte: adaptado pelos autores. 
Figura 2 - a) Rio da Captação (Perene); b) Curso d'água do Morro Vermelho (Temporário).

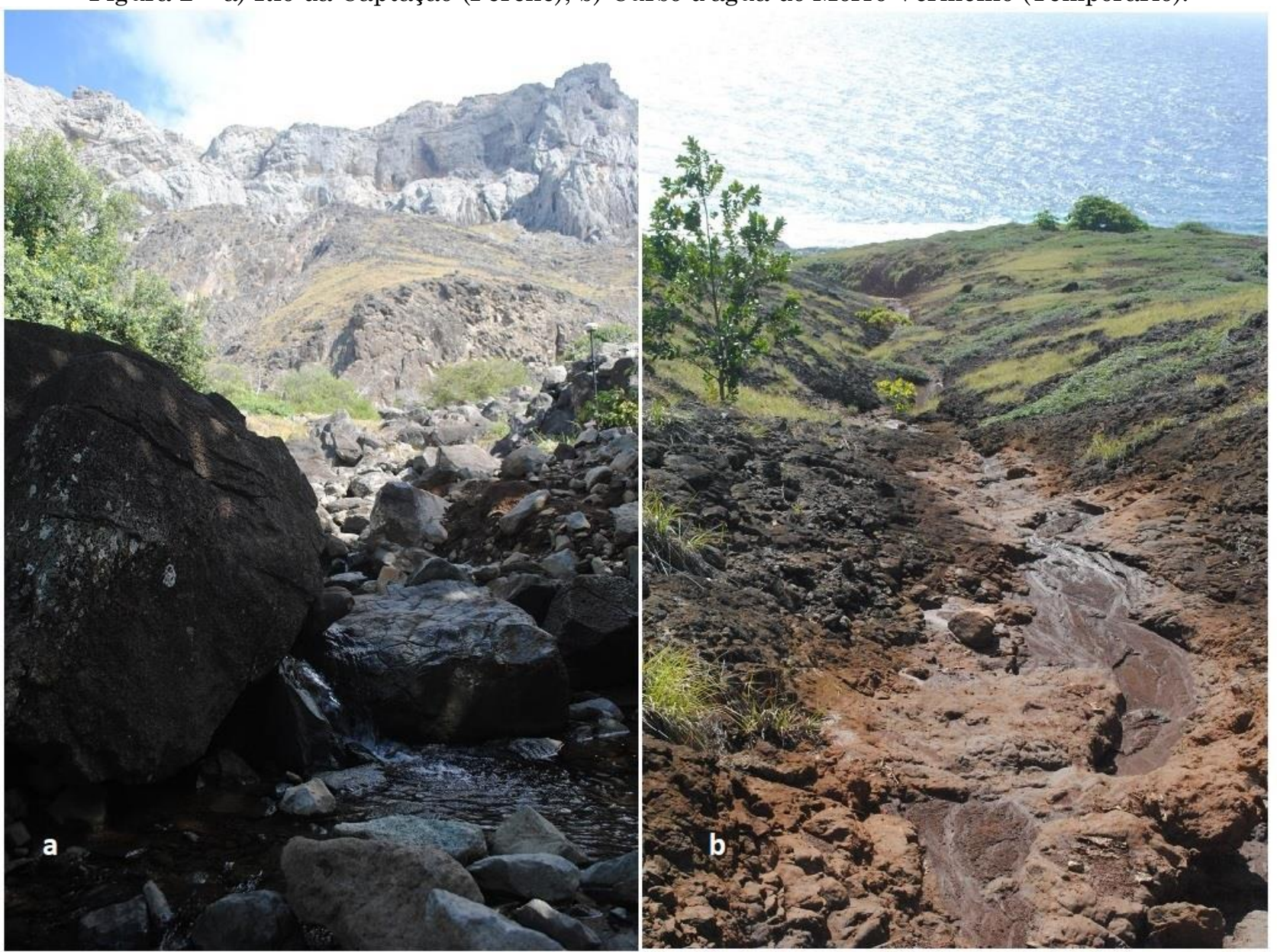

Fonte: dos autores.

\section{Geologia}

A clássica descrição geológica da ilha foi feita por Almeida (1962), que reconheceu cinco sucessões vulcanogênicas em Trindade em idade decrescente: o Complexo de Trindade e as formações Desejado, Morro Vermelho, Valado e Paredão, compostas de depósitos efusivo-piroclásticos nefelíticos a fonolíticos, diques e necks (Erro! Fonte de referência não encontrada.).

Figura 3 - Visão a partir do oceano para face Leste da Ilha da Trindade: c) E.xtinto Vulcão do Paredão d) Pico do Pão de Açúcar e) Praia das Tartarugas f) Pico do Desejado g) POIT (parte habitada) h) Platô Noroeste

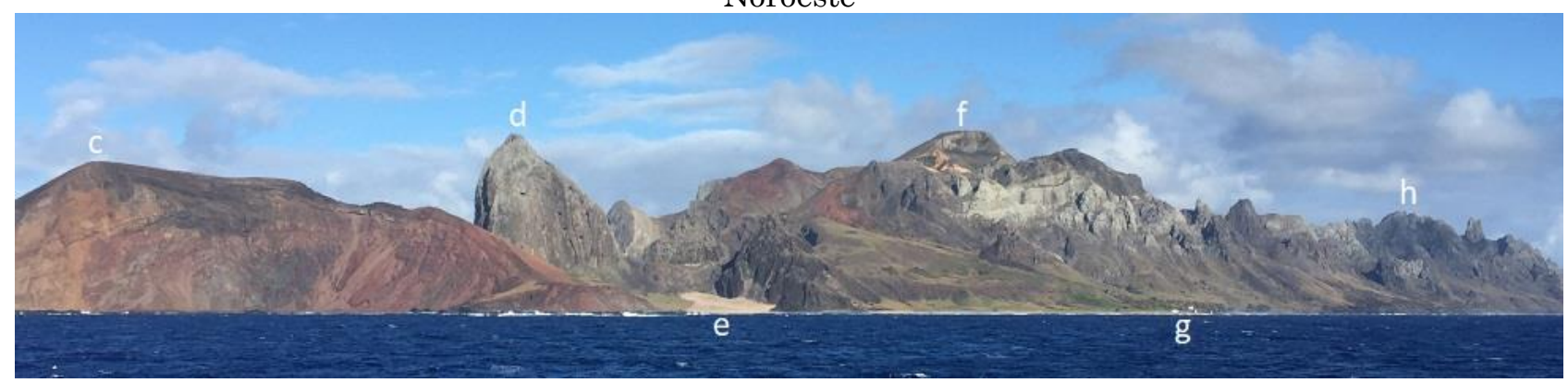

Fonte: dos autores. 
Os dados geocronológicos completos situam o pico do vulcanismo subaéreo de Trindade entre o Plioceno Inferior e o Pleistoceno Médio, ou seja, 3,9 a 2,5Ma, mas a atividade vulcânica foi completamente interrompida apenas em 0,25Ma. Evento registrado na região do Vulcão do Paredão, e que representa a última atividade vulcânica no território brasileiro (PIRES et al., 2016). Sendo o Vulcão do Paredão o único lugar no Brasil em que ainda pode reconhecer os restos de um vulcão extinto (CORDANI, 1970) (Figura 4). O ambiente geológico da ilha é constituído de rochas básicas e alcalinas, e depósitos sedimentares pleistocênicos holocênicos (CASTRO, 2010).

Figura 4 - Extremo Sul da Ilha da Trindade: i) Parte do extinto Vulcão do Paredão j) Parcel das Tartarugas k) Pico Pão de Açúcar l) Praia das Tartarugas.

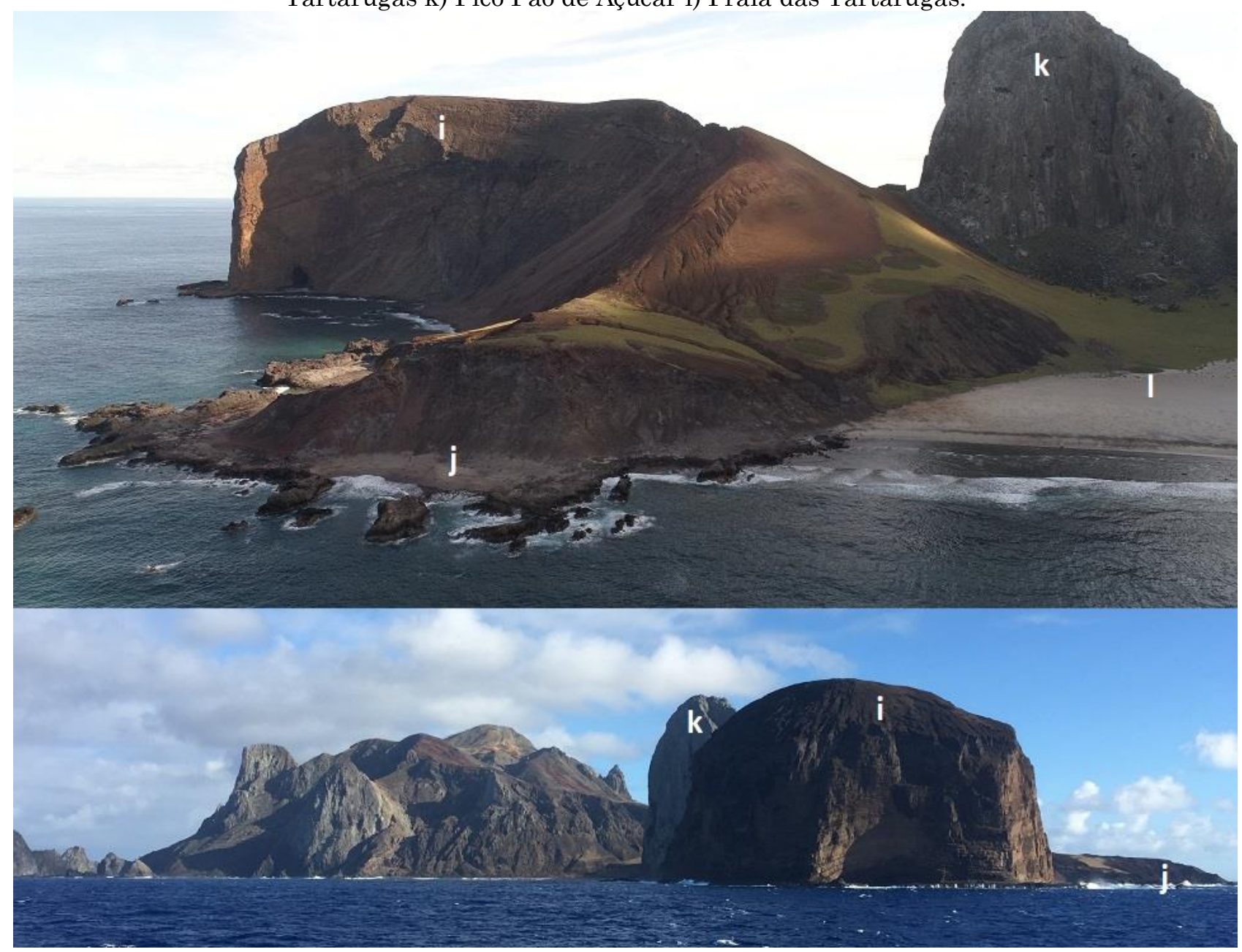

Fonte: dos autores.

\section{Clima}

O clima predominante na Ilha da Trindade é do tipo Oceânico Tropical (MORH et al., 2009). A temperatura média anual é de $25,3^{\circ} \mathrm{C}$, e os ventos com direção predominantes do Quadrante Leste (Figura $5)$.

De acordo com Pedroso et al. (2018), o mês de novembro é o mês mais chuvoso em 
Trindade, acumulando em média um total de $215 \mathrm{~mm}$, seguido do mês de outubro, com cerca de $186 \mathrm{~mm}$. Os meses mais secos são janeiro e fevereiro, com acumulado médio em torno de $64 \mathrm{~mm}$. É importante salientar que a ilha está sujeita frequentemente ao fenômeno Pirajá, terminologia local para as chuvas Orográficas que ocorrem em função da variação altimétrica na ilha.

Figura 5 - Direção de Ventos na Ilha da Trindade, Atlântico Sul no período de 2008 a 2018. Elaborado a partir dos dados da Estação Meteorológica da Ilha da Trindade, EMIT.

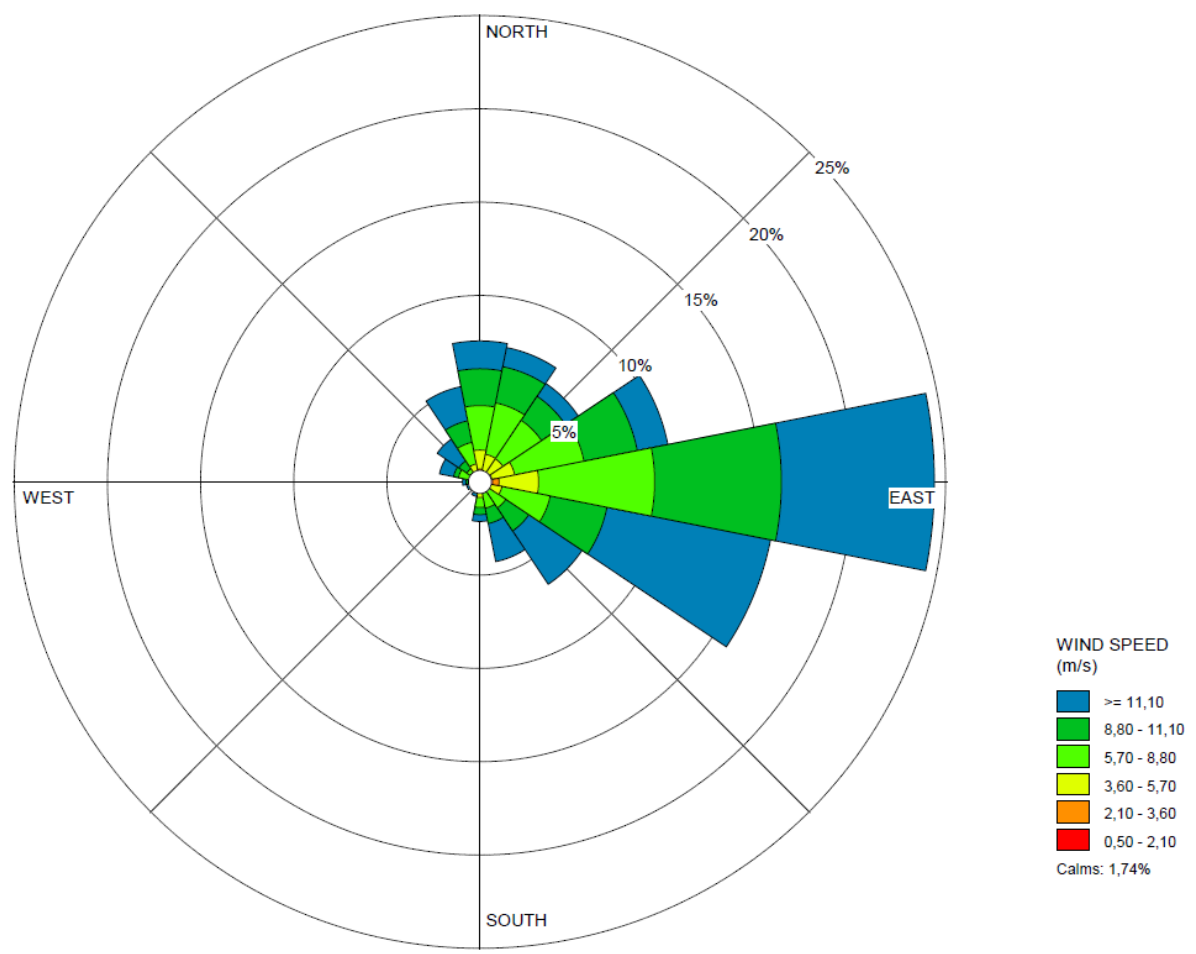

Fonte: Marinha do Brasil, 2018. Organização dos autores, 2019.

Solos

De acordo com Sá (2010), o solo predominante na Ilha da Trindade é o Neossolo abrangendo cerca de 55\%, podendo variar de Litólico e Regolitico; seguidos pelos Cambissolos Háplico com 30\% e; os Organossolos Fólicos com 10\%, sendo que os $5 \%$ restantes da área da área da ilha refere-se a afloramento rochoso.

Ainda de acordo com Sá (2010) e Machado et al. (2017) em função das peculiaridades dos materiais de origem incomuns como rochas vulcânicas jovens e sedimentos bioclásticos carbonáticos, os ambientes de exceção de florestas de samambaias gigantes em escarpas influenciadas pela umidade orográfica e, as interações específicas entre substratos e atividade biológica com colonização da avifauna, ornitogênese e fosfatização, são os potenciais produtores de solos.

\section{Uso e Cobertura da Terra}

Até o Século XVII, florestas cobriam $80 \%$ da Ilha (ALVES, 1998). Essas florestas ainda 
estavam vivas e saudáveis em 1700, de acordo com os relatos, quando a ilha foi visitada pelo famoso astrônomo Edmund Halley (16561742) (MURPHY, 1915). Porém, das duas visitas em 1881 e 1889, Sir Edward Frederick Knight (1852 - 1925) relatou uma floresta morta (ALVES; SILVA, 2016 apud KNIGHT $1884 ;$ 1892). As causas de tais degradações podem ser seguramente atribuídas às sucessivas ocupações da Ilha por humanos e seus animais domésticos.

Corroborando com as publicações e relatos escritos sobre a Ilha, Alves e Silva (2016) advogam que as ocupações e devastação da Ilha da Trindade tiveram início muito antes dos primeiros relatos sobre sua fauna e flora. Os autores ainda complementam que as sucessivas ocupações humanas introduziram cabras, javalis, ovelhas, equinos e cães cujas populações se tornaram ferais, pressionando ainda mais a cobertura vegetal já em declínio.

\section{Caminhos e materiais utilizados}

Para a elaboração deste trabalho, foi realizada ampla revisão bibliográfica de trabalhos desenvolvidos na ilha, dos mais diversos temas e, também, expedições científicas, necessárias dado isolamento da ilha. As expedições a campo para realização deste trabalho ocorreram no ano de 2018 nos meses de abril, com estadia de aproximadamente três dias na ilha e, entre os meses de maio e junho, em um período de 45 dias, onde foi percorrida toda ilha para validação dos mapas gerados.

\section{Dados da área}

Os planos de informações geográficos vetoriais (shapefiles) foram obtidos através de vetorização da Carta Náutica $n^{\circ} 21$, Ilhas ao Largo - Ilha da Trindade, originais no formato raster disponibilizadas no site do Centro Hidrográfico da Marinha (CHM), Marinha do Brasil na escala de 1:15.000.

Também, para melhor acurácia dos dados topográficos foi realizado no ano de 2018 levantamento topográfico com a utilização de Global Position System (GPS) - Real Time Kinematic (RTK) na ilha.

Para validação dos mapas, nas áreas inacessíveis por questões topográficas da ilha, foi utilizado ortofotomosaico na escala de 1 : 6.000, Projeção UTM - Zona 26S (WGS-84), do ano de 2012, obtido por processo de aerofotogramétrico digital através de voo por helicóptero, disponibilizado para pesquisa pela Diretoria de Hidrografia e Navegação (DHN) da Marinha do Brasil (2017).

\section{Operações de Geoprocessamento}

Os mapas foram elaborados com os softwares SAGA GIS 6.4.0, disponível para download gratuitamente no diretório $<$ https://sourceforge.net/projects/saga-gis$b r />$ e $\operatorname{ArcMap}^{\mathrm{TM}}$ 10.3.2. produzido pela ESRI ${ }^{\mathrm{TM}}$. A utilização do software SAGA GIS 6.4.0 para processamento dos dados se deu por ser um software livre e aberto. A Figura 6 apresenta em fluxograma todas as etapas realizadas em SIG utilizadas neste trabalho. 
Figura 6 - Fluxograma das etapas de SIG.

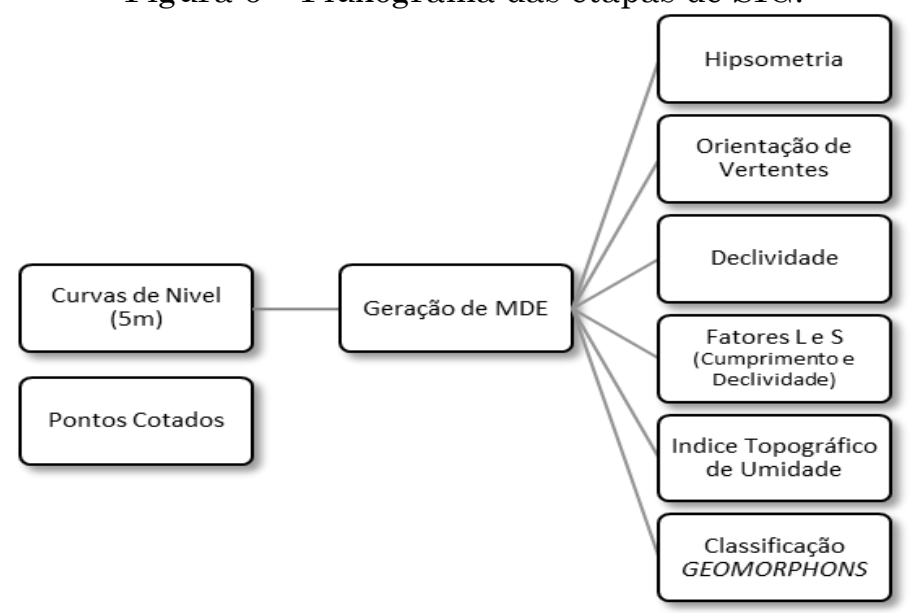

Fonte: organizado pelos autores

A geração do Modelo Digital de Elevação (MDE), foi feita com pixel em 5 metros (curvas de nível) na escala de 1:10.000, com a ferramenta Topo to Raster, componente do módulo 3D Analyst do ArcMap ${ }^{\mathrm{TM}}$ a partir da TOPOBATIMETRIA da Ilha da Trindade concedida pela Marinha do Brasil. Os mapas derivados do MDE têm escala 1:10.000.

O MDE foi importado para o software SAGA GIS e com a ferramenta Terrain Analysis foi gerado o processamento dos dados, como demonstrado na Figura 7, logo após foram exportados para ArcMap ${ }^{\text {TM }}$ onde foram confeccionados os mapas.

Figura 7 - Sequência de trabalho para geração das análises em SAGA GIS.

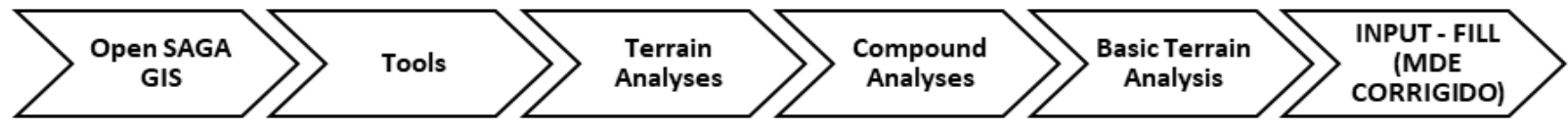

Fonte: organizado pelos autores.

\section{Mapa de Hipsometria}

Para a hipsometria, foi gerado a partir do MDE, com pixel em 5 metros (curvas de nível) na escala de 1:10.000, as classificações estão representadas a cada 25 metros de diferença altimétrica até a cota de 250 metros de altitude, após, são demarcadas a cada 100 metros.

\section{Mapa de Declividade}

O mapa de declividade foi classificado de acordo com o proposto pela Embrapa (1999), conforme Tabela 1 , a partir do MDE com pixel em 5 metros (curvas de nível) na escala de 1:10.000.

\section{Mapa do Fator LS}

O Mapa do Fator LS, é parte da Equação Universal de Perda de Solos (USLE), foi obtido no software SAGA GIS na metodologia proposta por Desmet e Govers (1996). Estes 
desenvolveram um algoritmo para calcular o fator L, baseado na equação de Foster e Wichemair (1974), em que consideraram o fluxo acumulado como estimativa do comprimento de rampa, em que LS: fator topográfico; X: comprimento da vertente (m); e D: declividade do terreno (\%).

Tabela 1 - Classificação de Declividade proposta pela Embrapa (1999).

\begin{tabular}{cc}
\hline CLASSE DE RELEVO & DECLIVIDADE (\%) \\
\hline Plano & $0-3$ \\
Suave ondulado & $3-8$ \\
Ondulado & $8-20$ \\
Forte ondulado & $20-45$ \\
Montanhoso & $45-75$ \\
Escarpado & $>75$ \\
\hline
\end{tabular}

Fonte: adaptada de EMBRAPA, 1999.

$\mathrm{O}$ fator $\mathrm{L}$ representou a relação de perdas de solos entre comprimento do declive e comprimento de rampa de $25 \mathrm{~m}$ para os mesmos fatores solo, chuva, grau de declive, cobertura e manejo. $\mathrm{O}$ fator $\mathrm{S}$ trata da relação de perdas de solo entre um declive qualquer e um declive de 9\%, sendo apresentada uma equação para possíveis ajustes às características locais (BESKOW et al., 2009).

A classificação para análise foi feita através do método de Classificação Natural Breaks, utilizando-se 5 classes, sendo os intervalos da seguinte forma: $0-4.186$ (Muito Baixo); 4.186 - 8.152 (Baixo); 8.152 - 11.897 (Médio); 11.897 - 16.303 (Alto) e 16.303 56.180 (Muito Alto).

\section{Orientação de Vertentes}

Para a obtenção das Orientações de Vertentes foi utilizada a ferramenta Raster Surface -
Aspect no ArcMap ${ }^{\mathrm{TM}}$ a partir do Modelo Digital de Elevação (MDE). As vertentes foram classificadas a cada $27,5^{\circ}$ de direção a partir do grau 0 , como Norte.

\section{Classificação do relevo em GEOMORPHONS}

A proposta de classificação da morfologia do relevo por Geomorphons foi sugerida por (JASIEWICZ; STEPINSKI, 2013), que analisa a similaridade textural do Modelo Digital de Elevação (MDE), considerando as variações dos níveis de cinza entre uma célula central (pixel do centro) e as células vizinhas, considerando que a célula central for maior, assume o $(+=$ "superior", - = “inferior" e $0=$ “ igual ").

Para caracterizar a altura do relevo além da diferença de altura, se faz necessária a distância do ângulo de direção dos pontos vizinhos em relação à célula central (ângulos Zenith e Nadir). Para esse cálculo, são traçados perfis para as principais direções a partir da célula central "lookup distance" (L), como na Fonte: , extraídos do MDE.

Para o processamento do MDE e gerar o arquivo .TIF geomorphons, utilizou-se o recursos on-line disponibilizado no diretório $<$ http://sil.uc.edu/geom/app>. O código também está disponível para a utilização no software de Sistema de Informações Geográficas (GIS). Foram utilizados os seguintes parâmetros para geração do mapa: 10 células de raio de busca (totalizando $50 \mathrm{~m}$ de raio) e nivelamento de áreas planas de $0,3^{\circ}$. 
Figura 8 - As representações das morfologias em 3D e seus correspondentes geomorphons (padrões ternários).

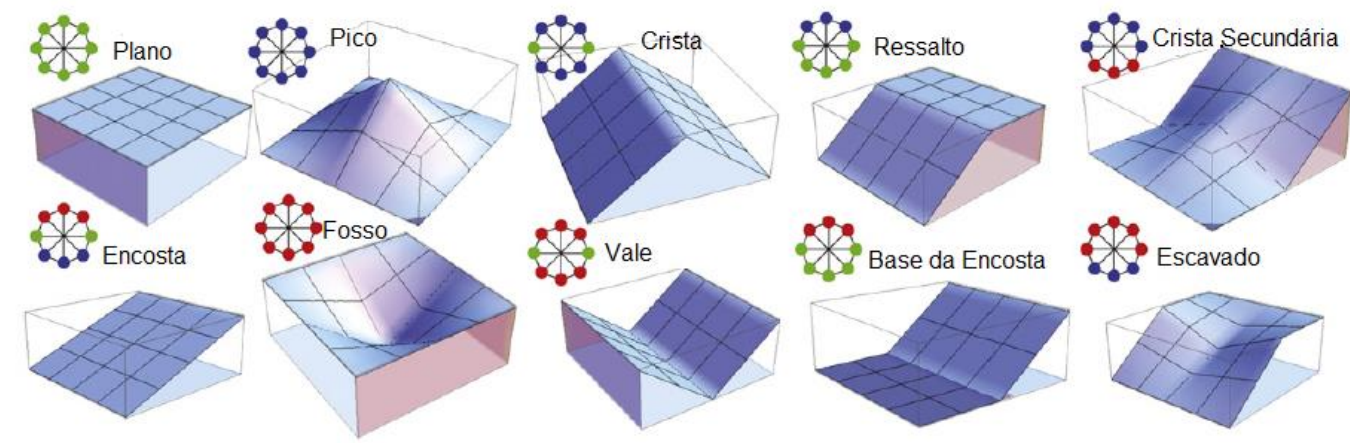

Fonte: adaptado de Jasiewicz e Stepinski (2013).

Mapa do Índice Topográfico de Umidade (ITU)

$\mathrm{Na}$ elaboração do mapa topográfico de Umidade, a ilha foi compartimentada em segmentos qualitativos utilizando-se o método de classificação Natural Breaks, do ArcMap ${ }^{\mathrm{TM}}$ em 5 classes de possibilidade de saturação do solo: Muito baixo; Baixo; Médio; Alto e Muito Alto.

O ITU é definido pelo logaritmo natural da razão entre a área de contribuição específica (As) e a tangente do ângulo da declividade, como mostra a Equação ITU= ln (As/tanß), no qual As corresponde à área de contribuição específica por unidade de largura ortogonal à linha de fluxo $(\mathrm{m} 2 \mathrm{~m}-1)$ e $B$ é a declividade expressa em graus radianos. A equação mostra que o ITU é função apenas de B, assim é adicionada a seguinte restrição: $0^{\circ}<$ $B<90^{\circ}$, pois se $B=0, \tan \beta=0$ e $1 / \tan B$ é

Tabela 2). As cotas de 200 a 300 metros de altitude, correspondem a $16,8 \%$ de toda área da ilha. Sendo $2,1 \%$ da Ilha da Trindade, as cotas acima de 500m (Figura 10), formam as porções mais altas da ilha, concentradas no infinito e, se $B=90^{\circ}, 1 / \tan 90=0, \ln 0$ é infinito.

A ideia por trás do ITU é proporcionar um índice de saturação relativa em uma bacia hidrográfica, onde se assume a similaridade hidrológica entre áreas com o mesmo valor de índice (BEVEN; KIRKBY, 1979).

\section{RESULTADOS E DISCUSSÕES}

\section{Análise morfométrica}

\section{Hipsometria da Ilha da Trindade}

A amplitude altimétrica da Ilha da Trindade, (Figura 9), é de aproximadamente 600 metros, sendo que as áreas com cotas entre 0 a 100 metros de altitude correspondem a $34 \%$ da área total da Ilha, enquanto a cota de 100 a 200 metros de altitude correspondem a $21,2 \%$ da

$$
\text { área total }
$$

centro como divisores de águas, com os Picos: Desejado, Verde, São Bonifácio e Trindade, onde Almeida (1962) caracterizou como a Sequência do Desejado.

As áreas de menor altitude correspondem às regiões classificadas por 
Angulo et al. (2018) como praias de areia, sudoeste, tais como as denominadas Praia da praias de cascalho e leques aluviais, Tartaruga, Praia do Paredão, entre outras. concentradas principalmente na região leste e

Tabela 2 - Caracterização Morfométrica da Ilha da Trindade, Atlântico Sul.

\begin{tabular}{ccc}
\hline ELEVAÇÃO & AREA EM M & PORCETAGEM \\
\hline$<0 \mathrm{~m}$ & 76750 & $1 \%$ \\
$0-25 \mathrm{~m}$ & 1350000 & $11,8 \%$ \\
$25-50 \mathrm{~m}$ & 853000 & $7,4 \%$ \\
$50-75 \mathrm{~m}$ & 785400 & $6,8 \%$ \\
$75-100 \mathrm{~m}$ & 797700 & $7,0 \%$ \\
$100-125 \mathrm{~m}$ & 704200 & $6,1 \%$ \\
$125-150 \mathrm{~m}$ & 652700 & $5,7 \%$ \\
$150-175 \mathrm{~m}$ & 567300 & $4,9 \%$ \\
$175-200 \mathrm{~m}$ & 520800 & $4,5 \%$ \\
$200-250 \mathrm{~m}$ & 1018000 & $8,9 \%$ \\
$250-300 \mathrm{~m}$ & 910700 & $7,9 \%$ \\
$300-400 \mathrm{~m}$ & 1654000 & $14,4 \%$ \\
$400-500 \mathrm{~m}$ & 1336000 & $11,7 \%$ \\
$500-600 \mathrm{~m}$ & 240500 & $2,1 \%$ \\
Área Total & 11467050 & $100 \%$ \\
\hline
\end{tabular}

Fonte: organizada pelos autores.

Figura 9 - Mapa Hipsométrico da Ilha da Trindade. 


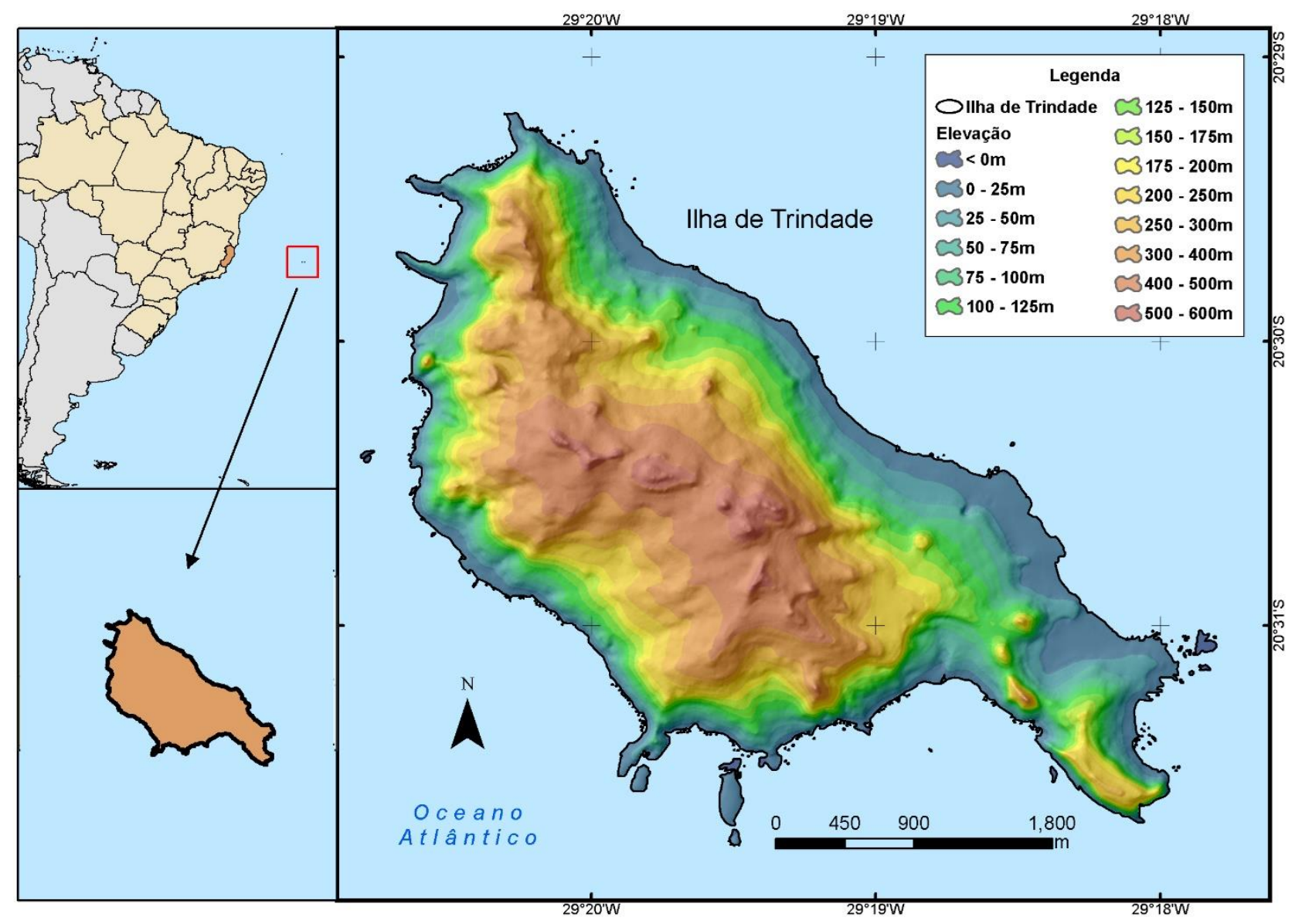

Fonte: organizado pelos autores.

Figura 10 - Distribuição das porções mais altas da ilha da Trindade no Atlântico Sul vista a partir do mar, onde: m) Vulcão do Paredão n) Pico do Pão de Açúcar o) Pico do Grazinas p) Morro Vermelho q) Pico do Desejado r) Pico da Fazendinha s) Pico Monumento t) Platô do Obelisco.

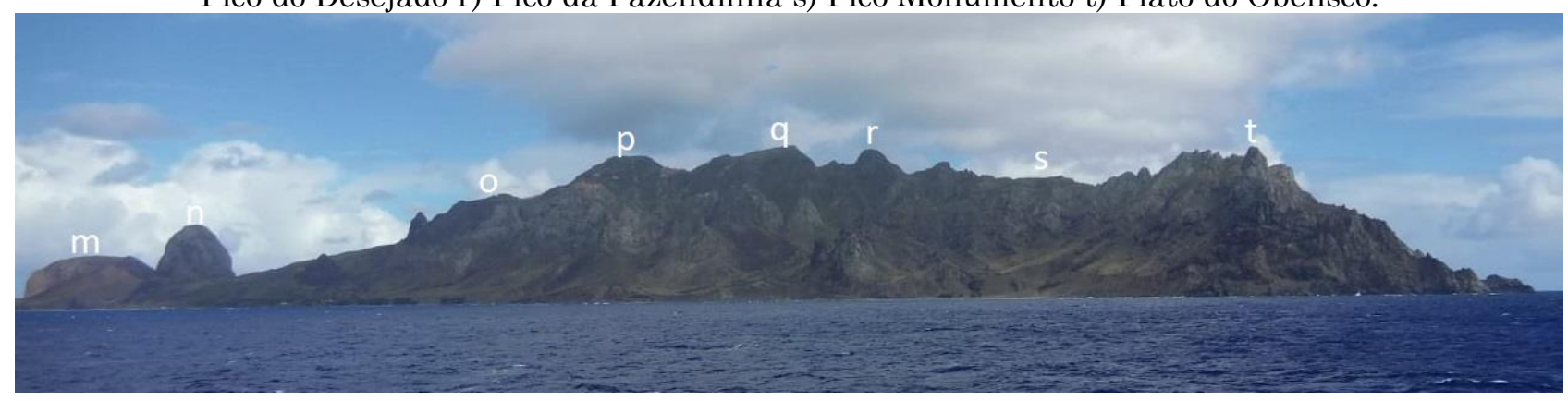

Fonte: dos autores.

\section{Declividade da Ilha da Trindade}

Quanto à declividade, pode-se verificar na Tabela 3, que na Ilha da Trindade, ocorre o predomínio das classes, Relevos Fortemente Ondulado e Montanhoso, com respectivamente $31,2 \%$ e $28,8 \%$, totalizando $60 \%$ do relevo da ilha. Já a classe Escarpado, ocorre em 24,3\% da Ilha e, as classes de declividade do tipo plano, suavemente ondulado e ondulado ocupam apenas 13,4\% da área total (Figura $11)$.

As classes Montanhosas e Escarpado ocorrem em todos os terços das vertentes na face Noroeste e Oeste (Figura 12) ocorrendo em algumas porções da porção superior e média da vertente na face Leste. 
Tabela 3 - Classificação da Declividade da Ilha da Trindade (EMBRAPA, 1999).

\begin{tabular}{ccc}
\hline CLASSES & Área em m $\mathbf{~}^{2}$ & PORCENTAGEM \% \\
\hline Plano (0-3\%) & 98550 & $0,9 \%$ \\
Suave ondulado (3-8\%) & 294200 & $2,6 \%$ \\
Ondulado (8-20\%) & 1135100 & $9,9 \%$ \\
Forte ondulado (20-45\%) & 3578225 & $31,2 \%$ \\
Montanhoso (45 - 75\%) & 3576475 & $31,2 \%$ \\
Escarpado (>75\%) & 2784000 & $24,3 \%$ \\
\hline
\end{tabular}

Fonte: organizada pelos autores.

Em relação às classes Fortemente

Ondulado e Montanhoso, estão presentes

principalmente na face oeste da Ilha, com

destaque para a face noroeste ( 
Figura 13). Tal característica sugere que estas faces estão recebendo menor interferência direta das ações de ventos do quadrante Leste que incidem sobre a ilha durante maior parte do ano e, esporadicamente estão recebendo a incidência de massas de ar no período entre Abril e Setembro (PEDROSO et al., 2018).

Outra constatação com o Mapa de
Declividade- é que as faces nos quadrantes Nordeste, Leste e Sudeste, Fonte: dos autores., são as que apresentam as menores declividades, devido a ação dos ventos predominantes de Leste, que de maneira geral, transportam mais umidade para ilha, durante a maior parte do ano, ocasionando intemperismos e erosão das encostas.

Figura 11 - Mapa de Declividade da Ilha da Trindade.

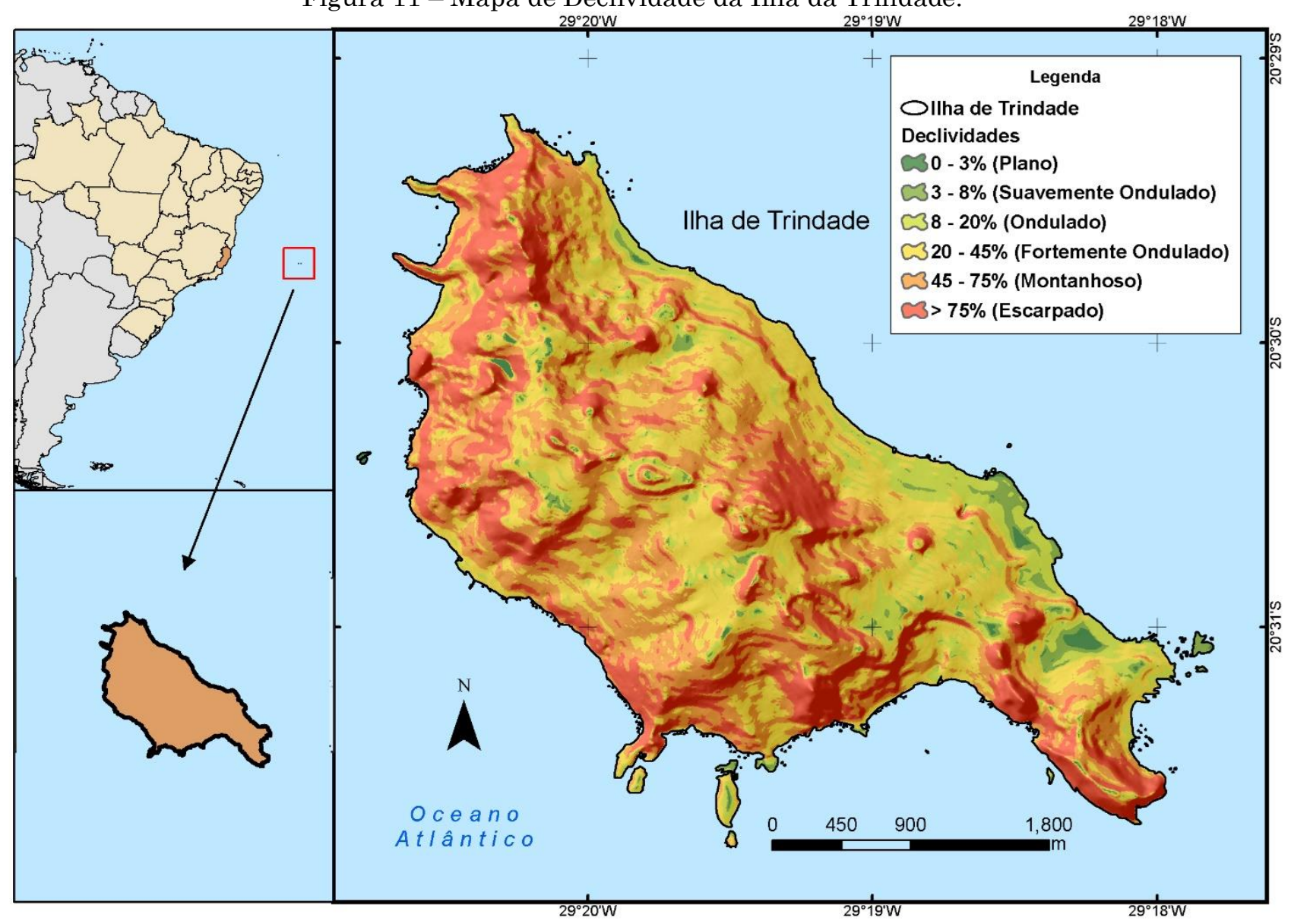

Fonte: organizado pelos autores.

Figura 12 - Vista da Ponta Norte, parcial da parte Noroeste e Pico do Monumento. 


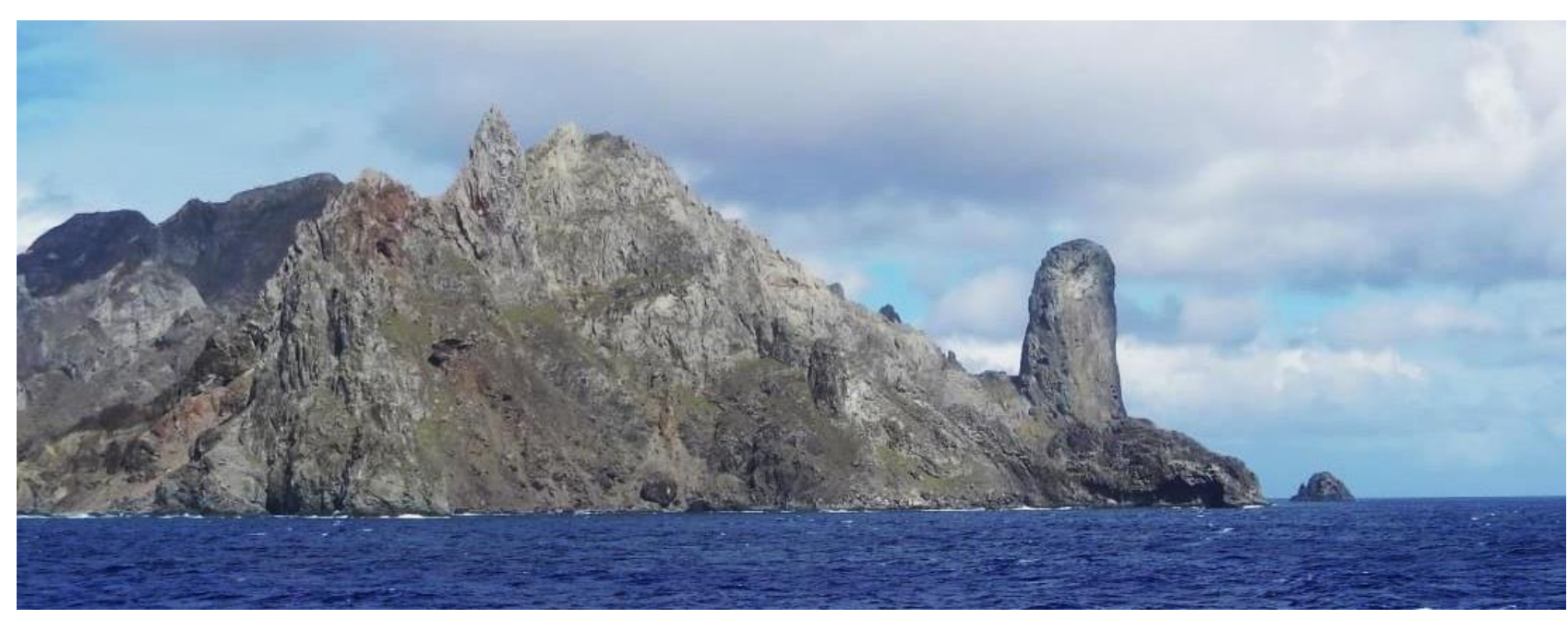

Fonte: dos autores. 
Figura 13 - Vista a partir do Pico Verde para face Oeste da Ilha, no centro da foto Praia do EME.

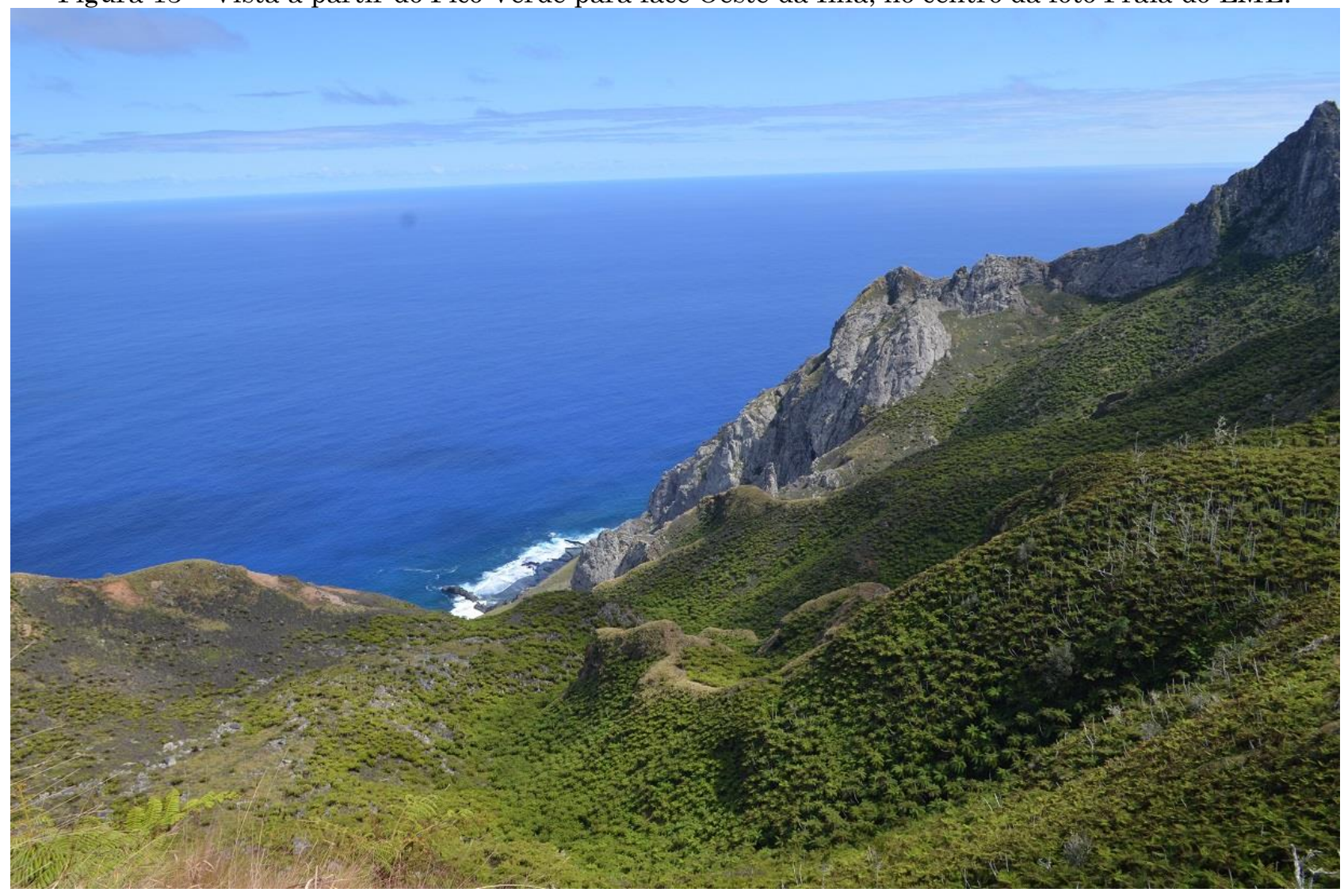

Fonte: dos autores.

Figura 14 - Vista da face Leste (do Morro Vermelho ao Valado) da Ilha da Trindade a partir da EMIT.

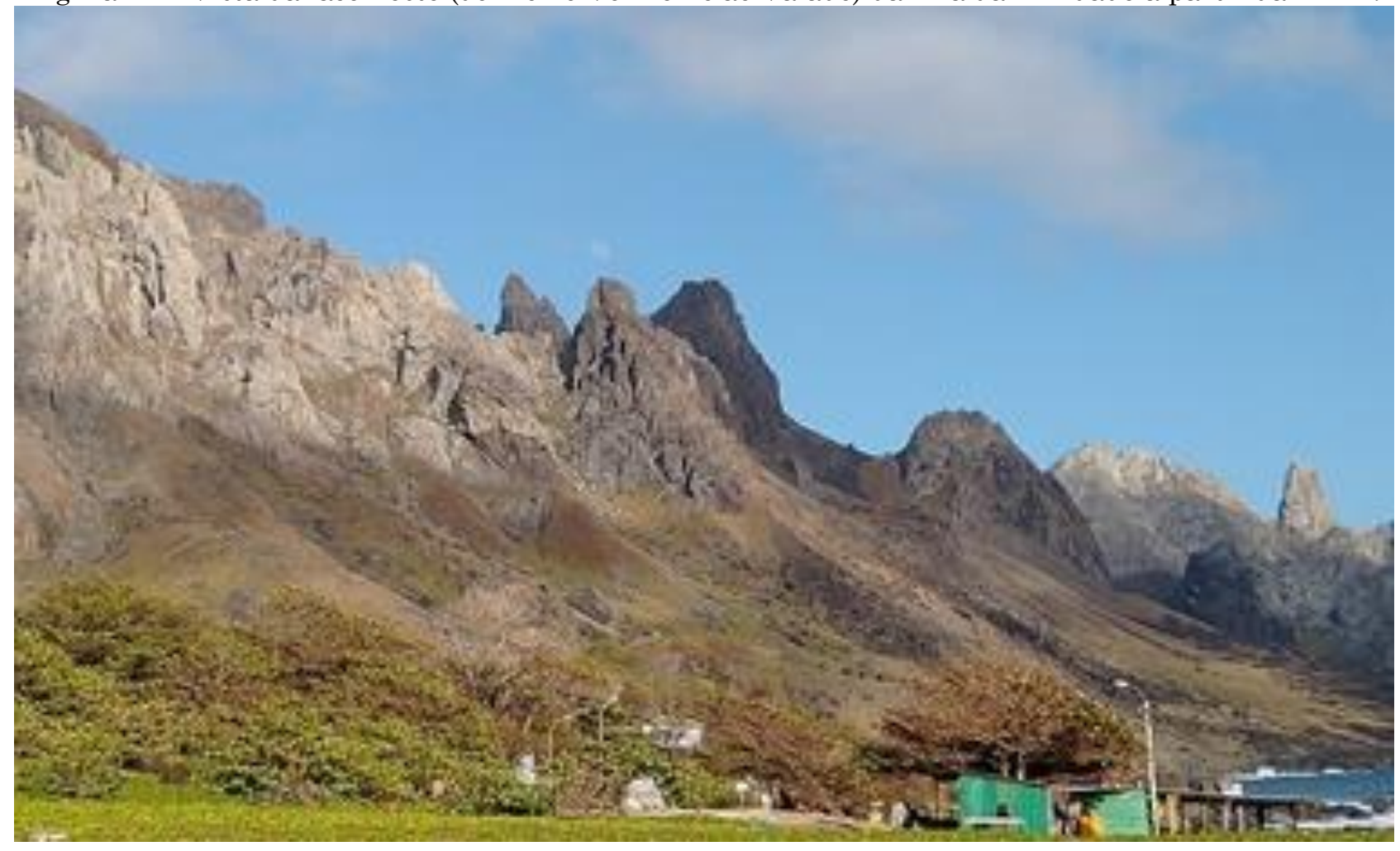

Fonte: dos autores. 


\section{Fator Topográfico LS}

$\mathrm{Na}$ Tabela 4, são apresentadas as áreas em $\mathrm{m}^{2}$ da ilha e, em percentagem do resultado do fator LS. A maior porcentagem do fator LS Baixo, representada pela cor verde claro $(4.186$ e 8.152), totalizando $30 \%$ de toda a área da
Ilha, seguido pelas classes Médio, com a cor amarela (8.152-11.897) com $26 \%$ e, a classe Muito Baixo, cor verde escuro (0-4.186), com 22\%. As classificações Alta (11.897 - 16.303), em laranja, tem 17\% e Muito Alta (16.303 56.180), em vermelho, 5\% da área total.

Tabela 4 - Resultados da Equação 2, fator topográfico LS.

\begin{tabular}{cccc}
\hline CLASSES & ÁREA EM m & & \\
\hline Muito Baixo & 2556100 & PORCENTAGEM & CORES \\
Baixo & 3464900 & $22 \%$ & VERDE ESCURO \\
Médio & 2928175 & $30 \%$ & VERDE CLARO \\
Alto & 1895225 & $26 \%$ & AMARELO \\
Muito Alto & 593750 & $17 \%$ & LARANJA \\
\hline
\end{tabular}

Fonte: organizada pelos autores.

Em todos os terços das vertentes das faces Noroeste e Oeste apresentaram a predominância dos maiores fatores LS, sugerindo encostas curtas e declivosas, quando comparado as vertentes da face Leste, com os menores fatores LS, o que sugere encostas mais longas e com declividade mais suaves (Figura 15 e 16).

Figura 15 - Mapa representando os resultados do Fator LS.

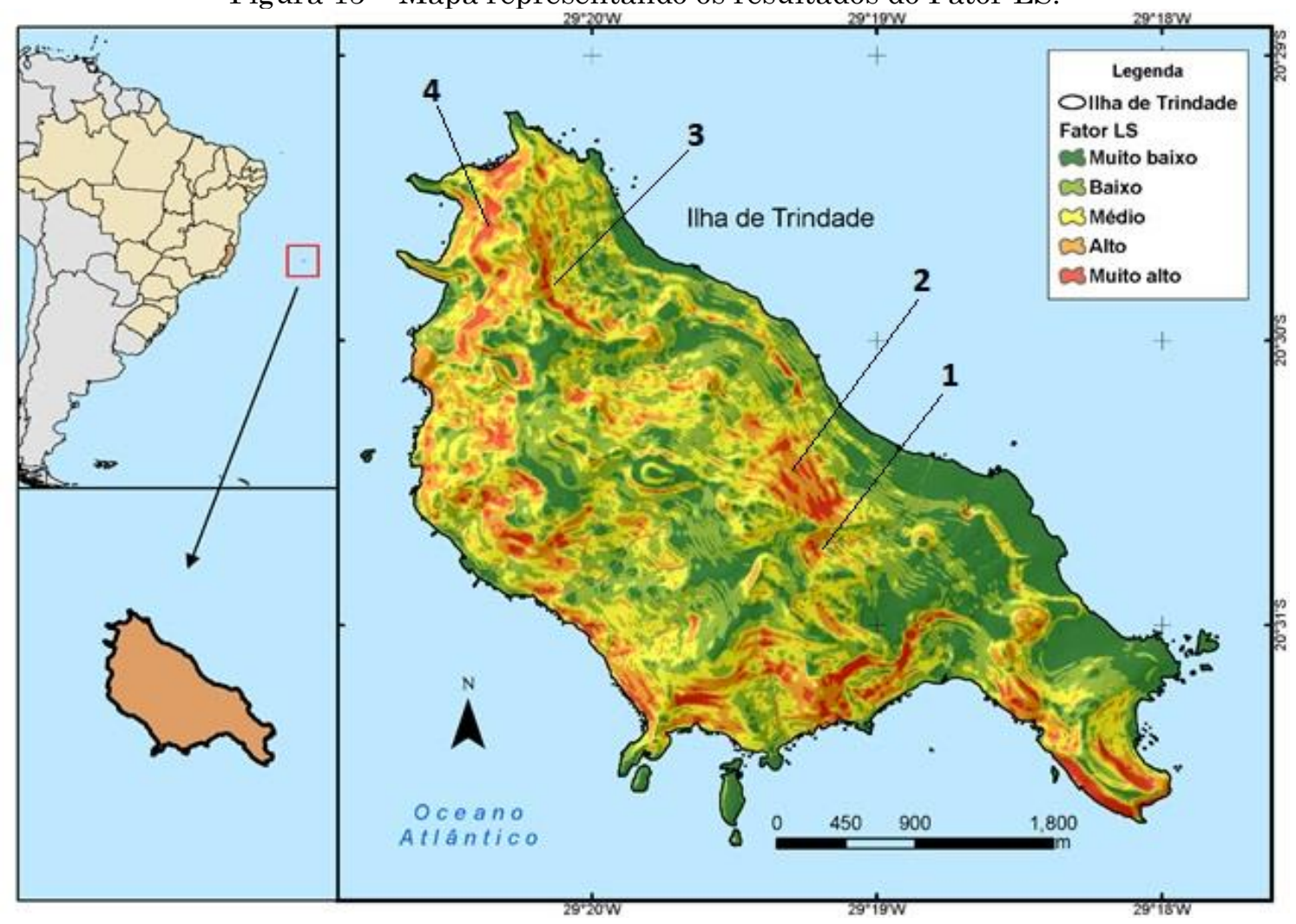

Fonte: organizado pelos autores. 
Figura 16 - 1) Pico do Grazina 2) Morro Vermelho 3) Subida do Platô do NE 4) Vista para W a partir do
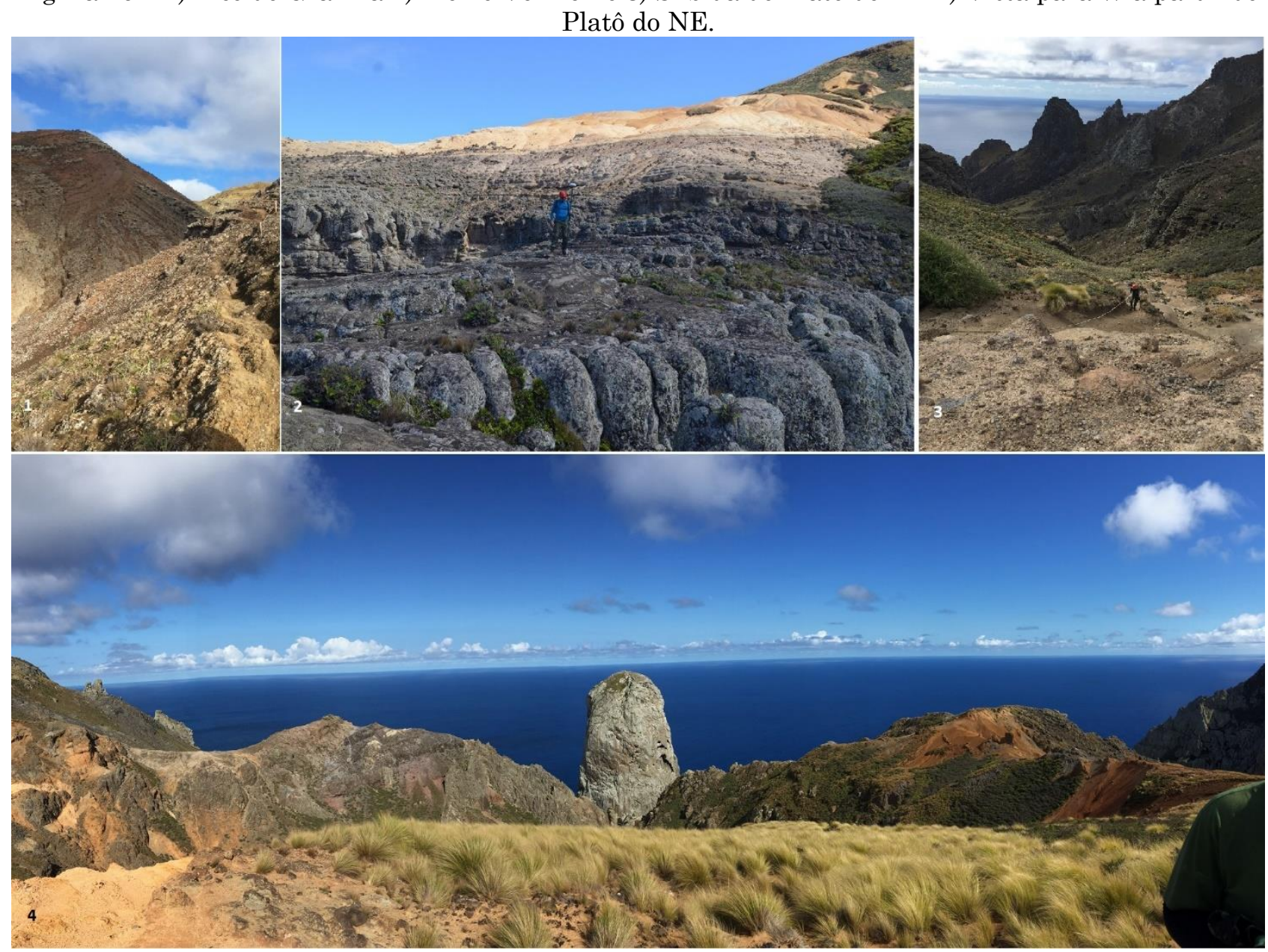

Fonte: dos autores.

Os elevados valores de fator LS encontrados nas porções Noroeste e Oeste indicam que são locais de alta suscetibilidade a erosão de solos, devido a uma alta declividade e um pequeno comprimento das vertentes, quando comparados a face Leste.

\section{Análise morfológica do relevo}

\section{Orientação das Vertentes}

\section{$\mathrm{Na}$}

Nas faces oeste, sudoeste e sul também são bem caracterizadas, sofrendo a incidência de ventos carregados de umidade principalmente entre os meses de junho a setembro, quando Anticiclone Subtropical do Atlântico Sul se move em direção à linha do Equador (costa) do Brasil (ANGULO et al., 2018). Nesta face são verificados declividades e fator LS moderados, o que indica uma morfogênese maior quando comparado ao setor Noroeste e, menor quando comparado a face Leste

, verifica-se as orientações das vertentes da Ilha da Trindade. As orientações para o quadrante Nordeste e Sudeste possuem a maior expressão em relação às demais, com respectivamente, $24,8 \%$ e $16,1 \%$ do total da ilha. As vertentes com os menores valores percentuais são as de Norte com $6,5 \%$, seguida 
pela Sudeste, com $7,7 \%$ da área total e Noroeste, com 7,8\% da área total, Figura 17.

As características das vertentes voltadas para o quadrante Leste estão associadas a maior morfogênese do relevo, devido a recorrências predominante de ventos quentes e úmidos a maior parte do ano (CALLIARI et al., 2016) culminando em menores valores de declividade e de fator LS.

A face noroeste também está bem definida, sendo protegida dos ventos de leste durante a maior parte do ano devido ao efeito orográfico, apresentando vertentes que recebem menor incidência de ventos quentes e úmidos e, das intempéries climáticas promovidas, corroborando para apresentarem elevada declividade (vertentes escarpas íngremes) e alto fator LS.

Nas faces oeste, sudoeste e sul também são bem caracterizadas, sofrendo a incidência de ventos carregados de umidade principalmente entre os meses de junho a setembro, quando Anticiclone Subtropical do Atlântico Sul se move em direção à linha do Equador (costa) do Brasil (ANGULO et al., 2018). Nesta face são verificados declividades e fator LS moderados, o que indica uma morfogênese maior quando comparado ao setor Noroeste e, menor quando comparado a face Leste

Tabela 5 - Porcentagem das orientações das vertentes da Ilha da Trindade.

\begin{tabular}{ccc}
\hline ORIENTAÇÃO & $\begin{array}{c}\text { ÁREA } \\
\text { EM M }\end{array}$ & $\begin{array}{c}\text { PORCENTAGEM } \\
\mathbf{\%}\end{array}$ \\
\hline PLANO & 8975 & $0,1 \%$ \\
NORTE & 713400 & $6,5 \%$ \\
NORDESTE & 2739000 & $24,8 \%$ \\
LESTE & 1612000 & $14,6 \%$ \\
SUDESTE & 847900 & $7,7 \%$ \\
SUL & 1151000 & $10,4 \%$ \\
SUDOESTE & 1770000 & $16,1 \%$ \\
OESTE & 1319000 & $12,0 \%$ \\
NOROESTE & 864000 & $7,8 \%$ \\
\hline
\end{tabular}

Fonte: organizado pelos autores.

Figura 17 - Mapa de Orientação das Vertentes da Ilha da Trindade. 


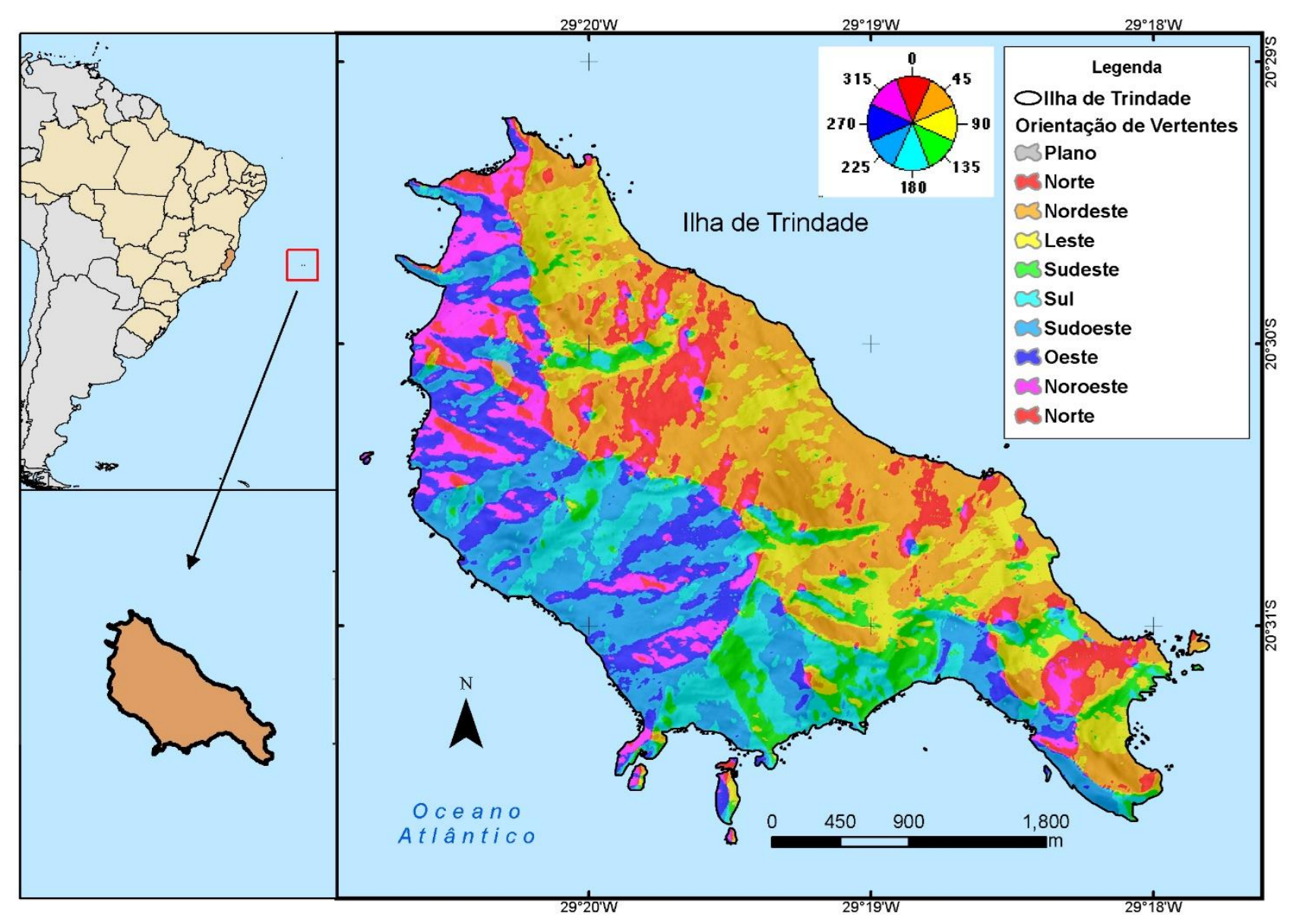

Fonte: organizado pelos autores.

Aspectos Morfológicos pelo método GEOMORPHONS

As configurações morfológicas de Trindade são caracterizadas como as com maiores representações da área total: Encostas (Slope) com 51,1\%; seguido de Crista Secundária (Spur) com 19,1\% de área e, Escavado ou Concavidade (Hollow) com 18,5\% da área total (Fonte: organizado pelos autores. 
Tabela 6). Já as com menores representações estão as áreas planas e os picos, cada, com apenas $0,3 \%$ da área total, ressaltos com $0,1 \%$ e fosso praticamente inexistentes (Figura 18).

Nas zonas denominadas de Hollow (Escavado/Concavidade), estão presentes os cursos fluviais da Ilha, podendo ser classificados em sua maioria como temporários. Dos rios perenes destaca-se o Rio da Captação que é utilizado para captação de água para consumo dos militares e pesquisadores que estão habitando a ilha (Figura 19).

Figura 18 - Mapa Morfológico Geomorphons da Ilha da Trindade.

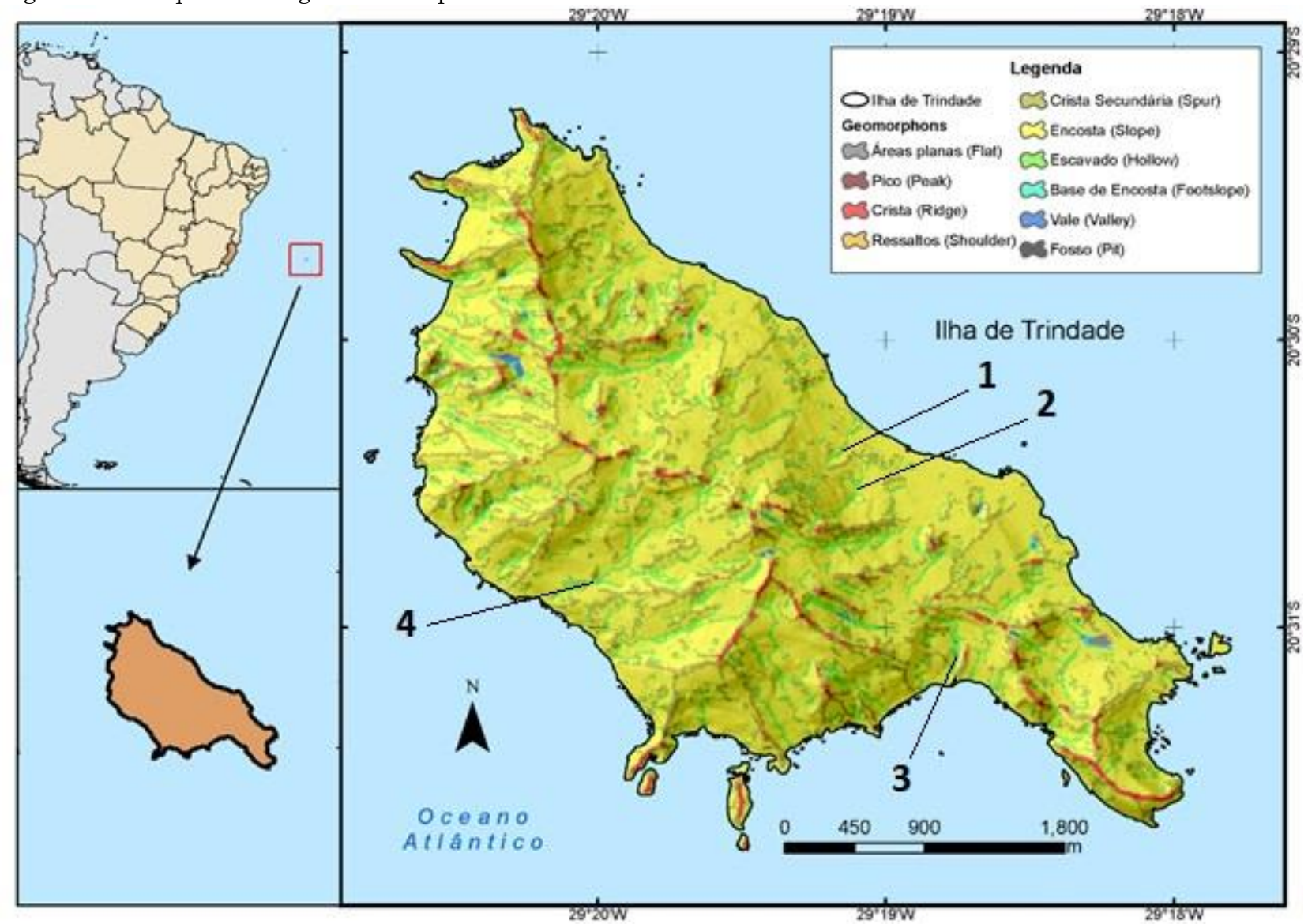

Fonte: organizado pelos autores. 
Tabela 6 - Representação das formas de relevo pelo método GEOMORPHONS.

\begin{tabular}{ccc}
\hline FORMA DO RELEVO & ÁREA $\left.\mathbf{( M}^{\mathbf{2}}\right)$ & ÁREA TOTAL (\%) \\
\hline Áreas planas (Flat) & 25175 & $0,3 \%$ \\
Pico (Peak) & 30075 & $0,3 \%$ \\
Crista (Ridge) & 240450 & $2,4 \%$ \\
Ressaltos (Shoulder) & 8700 & $0,1 \%$ \\
Crista Secundária (Spur) & 1932025 & $19,1 \%$ \\
Encosta (Slope) & 5768650 & $57,1 \%$ \\
Escavado/Concavidade (Hollow) & 1874700 & $18,6 \%$ \\
Base de Encosta (Footslope) & 107200 & $1,1 \%$ \\
Vale (Valley) & 112675 & $1,1 \%$ \\
Fosso (Pit) & 400 & $0,0 \%$ \\
\hline
\end{tabular}

Fonte: Organizado pelos autores.

Figura 19 - 1) Rio temporário no lado oriental de Trindade próximo ao POIT 2) Rio Perene no lado oriental de Trindade (rio da Captação) 3) Queda d'água Pedra da Garoupa na parte Sudoeste de Trindade (perene) 4) Rio do EME, parte oeste de Trindade (perene).

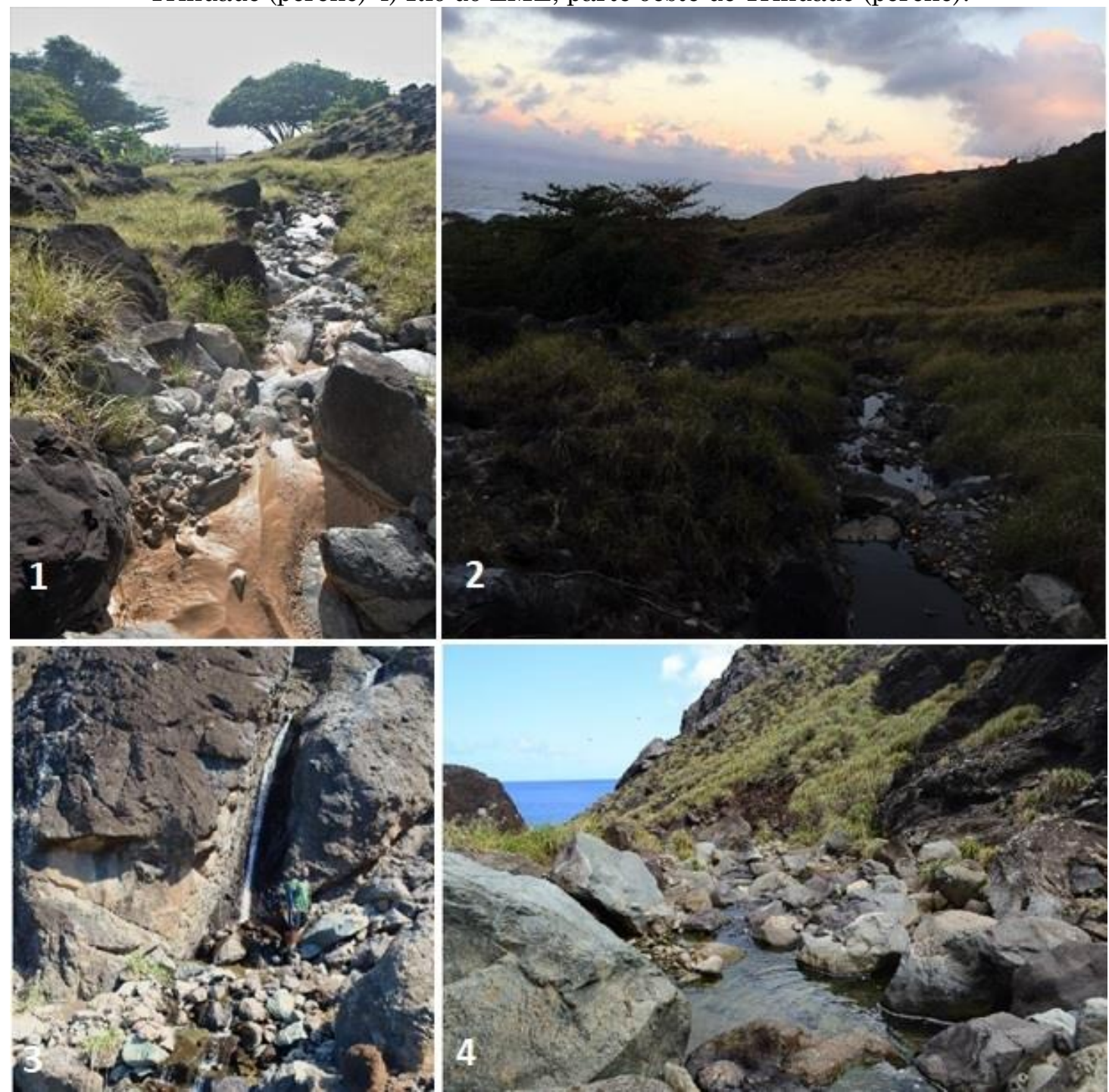

Fonte: dos autores. 
Associados ao Hollow ou Escavado/Concavidade estão presentes algumas feições em forma de anfiteatro, dominando principalmente à porção Leste e, em menor ocorrência na porção Oeste, sendo inexpressiva na face Noroeste. Concomitante a este fato, pode-se observar a presença de leques aluvias nas desembocaduras destas cabeceiras de drenagem, conforme descrito por (ANGULO et al., 2018), o que demonstra o poder erosivo das águas superficiais (Figura 20).

Figura 20 - Evento de chuva em junho de 2018, rio temporário proveniente do Morro Vermelho e desembocando na Praia da Calheta, parte leste de Trindade.

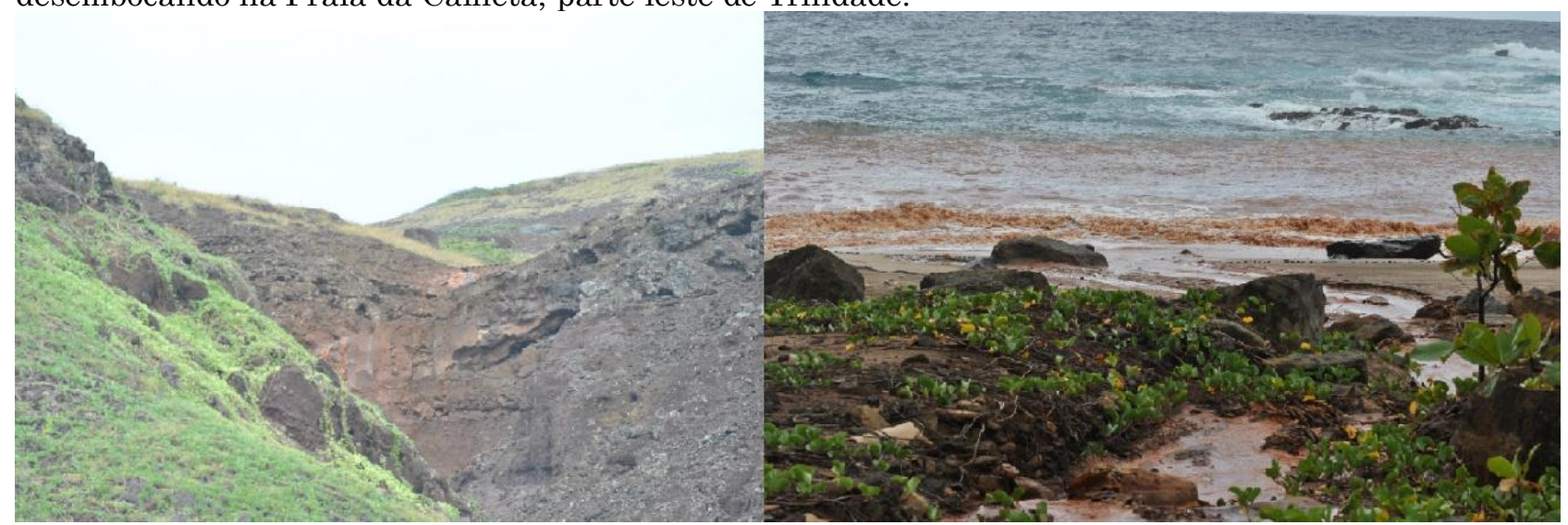

Fonte: dos autores.

As Cristas secundárias (Figura 21) ocorrem em 19,1\% da Ilha, correspondendo aos contrafortes ou divisores de águas secundários, mas que possuem importância para possibilitarem a formação de cabeceiras de drenagem pequenas, conforme descritos por (MARQUES; JUNIOR; OLIVEIRA, 2017).

Por outro lado, os picos e as cristas, ocorrem em $2,7 \%$ da área da Ilha da Trindade, Figura 22, tendo papel fundamental da divergência de fluxos superficiais, funcionando como divisores topográficos. Já as áreas planas estão presentes em apenas $0,3 \%$ da Ilha da Trindade, associadas a planícies costeira, praias e leques aluviais. 
Figura 21 - Vista a partir do Pico da Fazendinha para face Leste da Ilha.

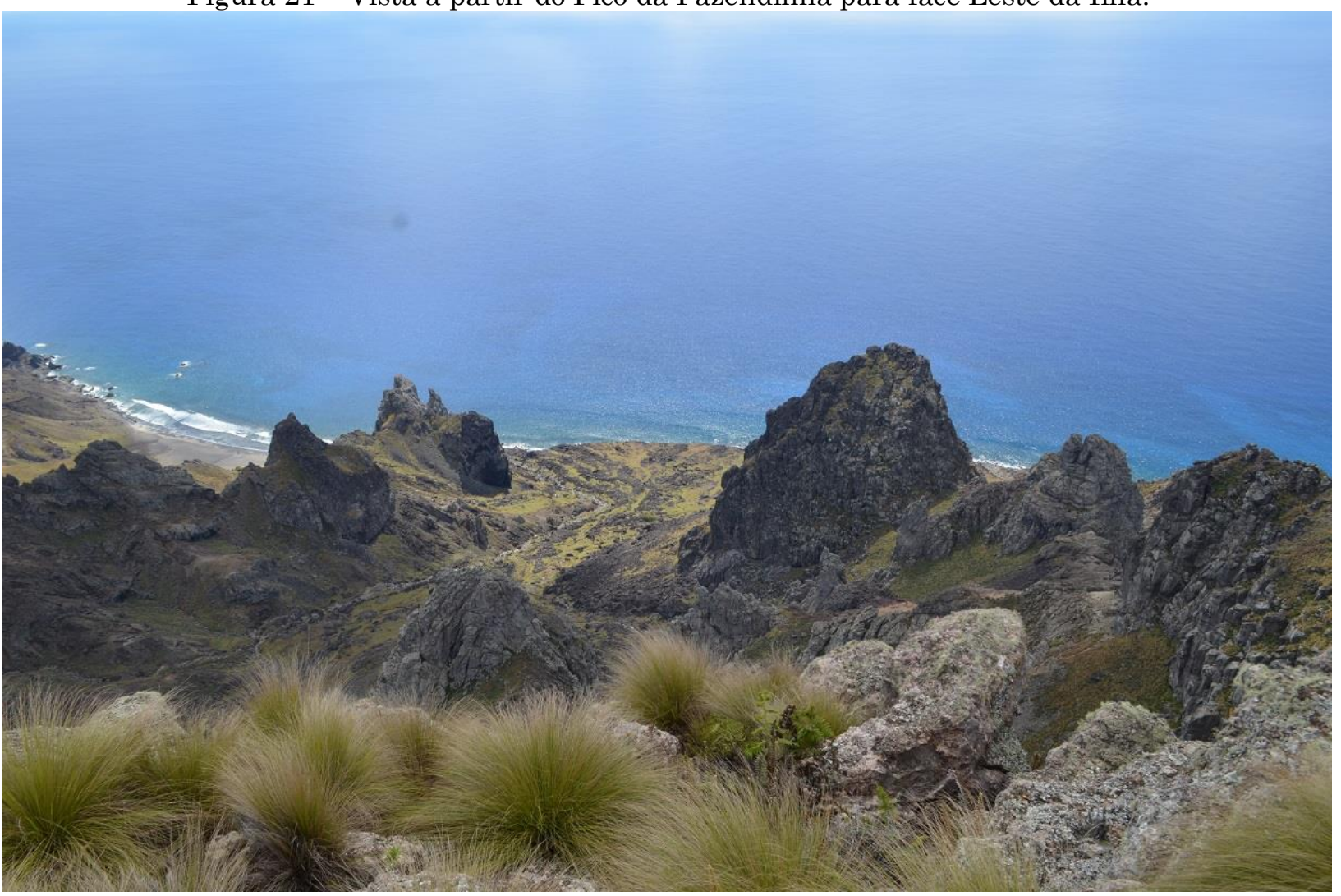

Fonte: dos autores.

Figura 22 - Vista do Pico da Fazendinha e o nordeste de Trindade a partir do Pico do Desejado: u) Praia das Cabritas v) Pico da Fazendinha w) Crista do Galo, extremo norte de Trindade.

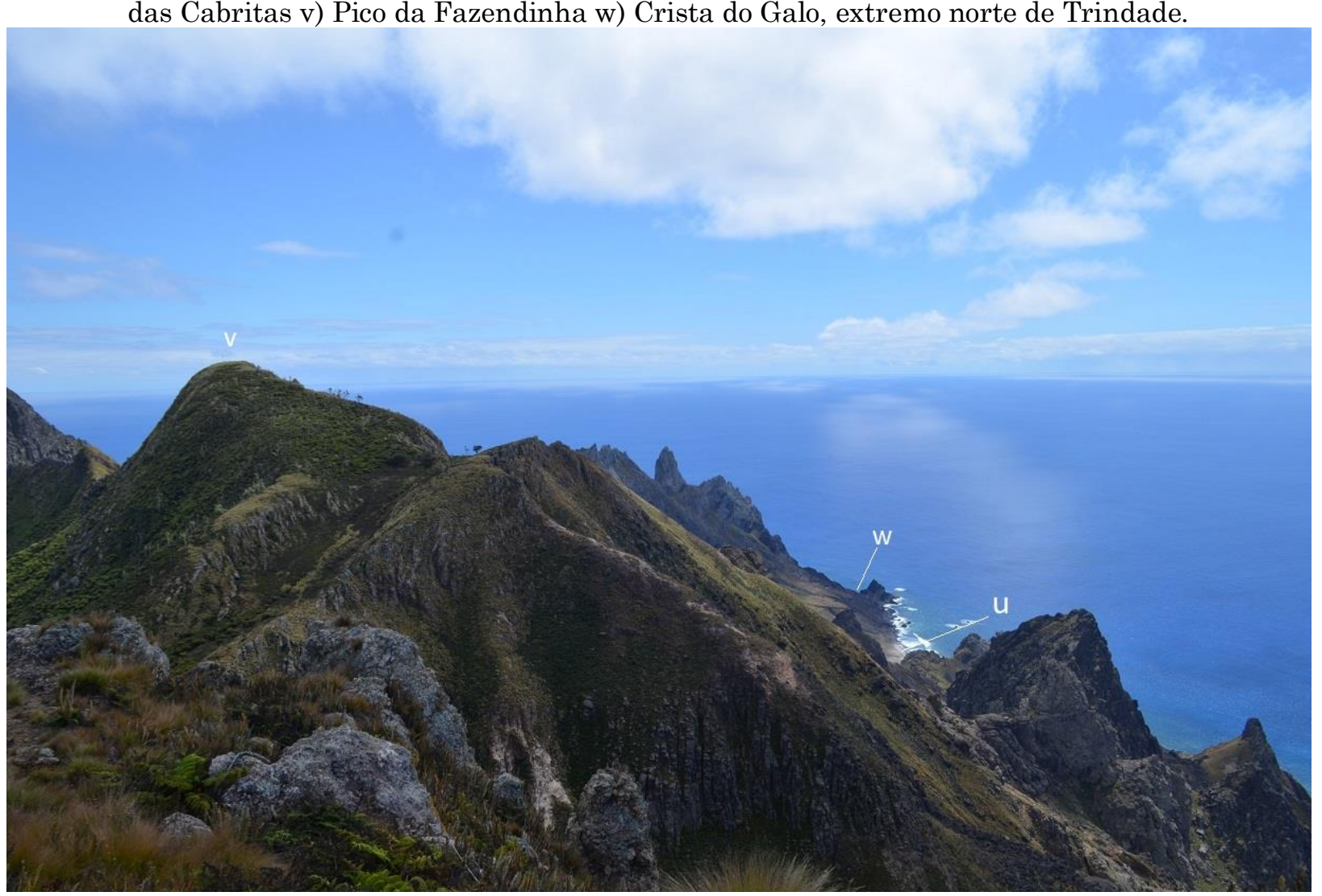

Fonte: dos autores. 
Índice Topográfico de Umidade (ITU)

Foram identificados as seguintes descrições dos índices topográfico de umidade (ITU) na Ilha da Trindade (Figura 23): a) Muito Baixo
(17,5\% da área total); b) Baixo (33,6\% da área total); c) Médio (30,6\% da área total); d) Alto (16,9\% da área total) e, e) Muito Alto (1,4\% da área total).

Figura 23 - Mapa do Índice Topográfico de Umidade (ITU) da Ilha da Trindade.

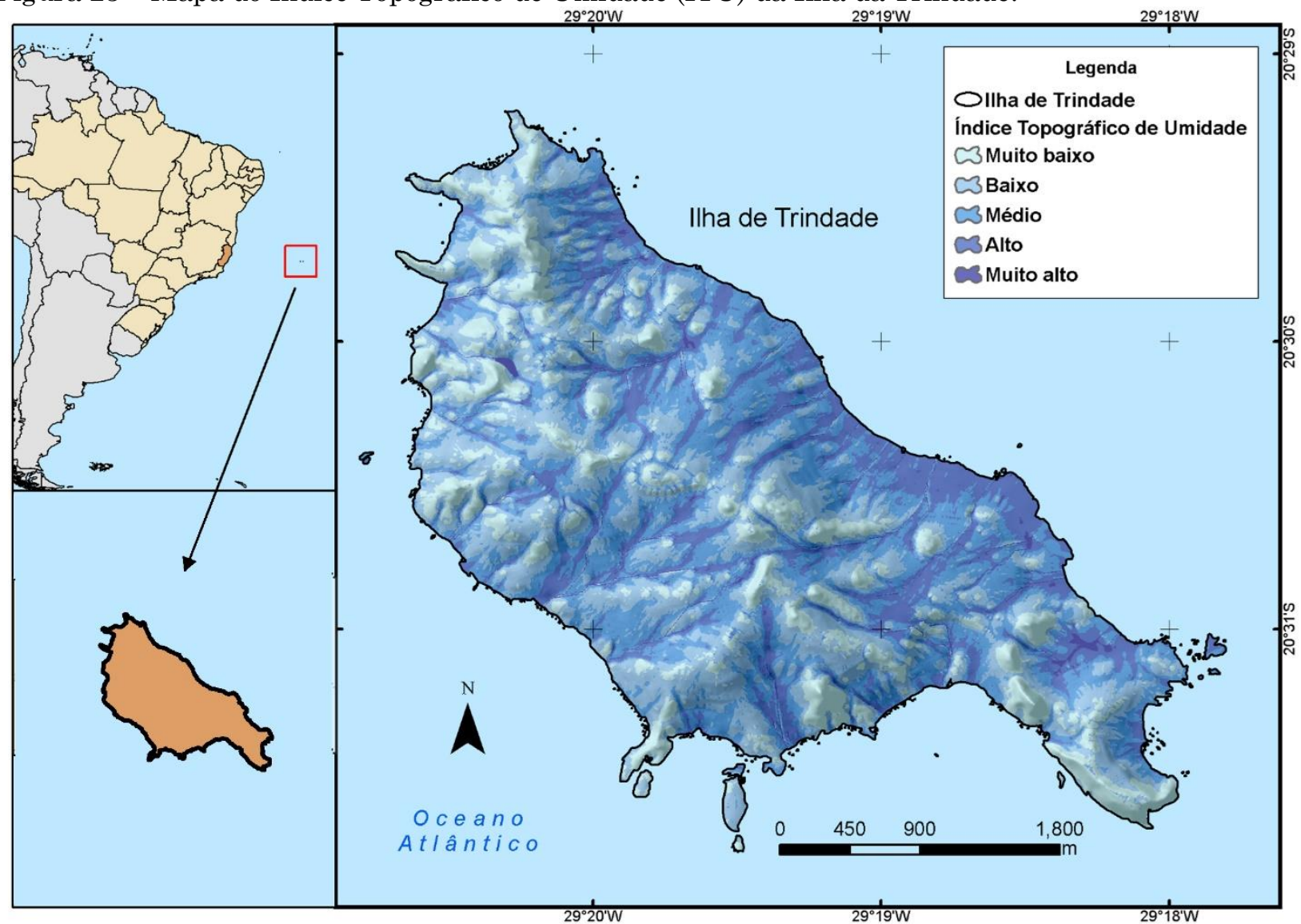

Fonte: organizado pelos autores.

As classificações de ITU Alto e Muito Alto são encontradas principalmente na porção Leste da Ilha da Trindade (Figura 24), muitas das vezes associados a cabeceiras de drenagem e feições morfológicas Hollow/Concavidade. Também, nessa porção da ilha são encontradas vertentes côncavas e baixos fatores LS, com a formação de expressivas áreas de convergências de águas, como apresentados na cor azul escuro.

$\mathrm{Na}$ face Noroeste, as drenagens estão concentradas em poucos canais, como encontrado nos resultados do Fator LS (Figura 25). Estas declividades foram classificadas principalmente como Muito Alto. Nesta porção da ilha tem-se paredões rochosos preservados, o que pode estar relacionado a posição geográfica onde situam-se, sendo uma região de menores ocorrências de incidências das intempéries climáticas nas encostas.

Os Picos e Cristas Geomorphons, denominados por Almeida (1962), como 
Sequência do Desejado, ocorrem os menores divisores de fluxos de água. índices de ITU, uma vez que se constituem

Figura 24 - Vista a partir da EMIT de parte das Encostas orientadas para Leste: x) Pico do Desejado. y) Parte da bacia hidrográfica do rio de Captação.

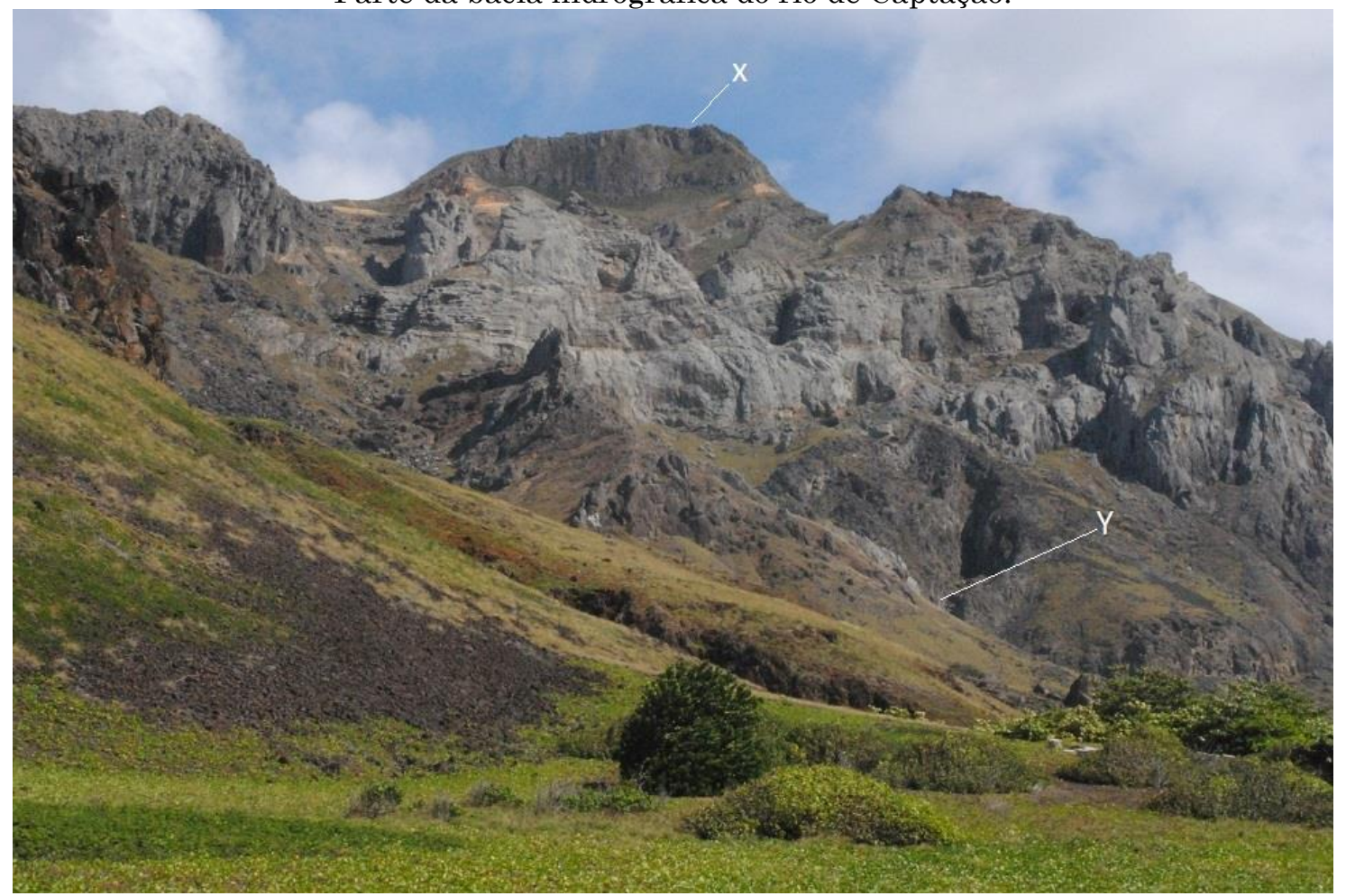

Fonte: dos autores.

Figura 25 - Vista Norte-Sul da Ilha da Trindade.

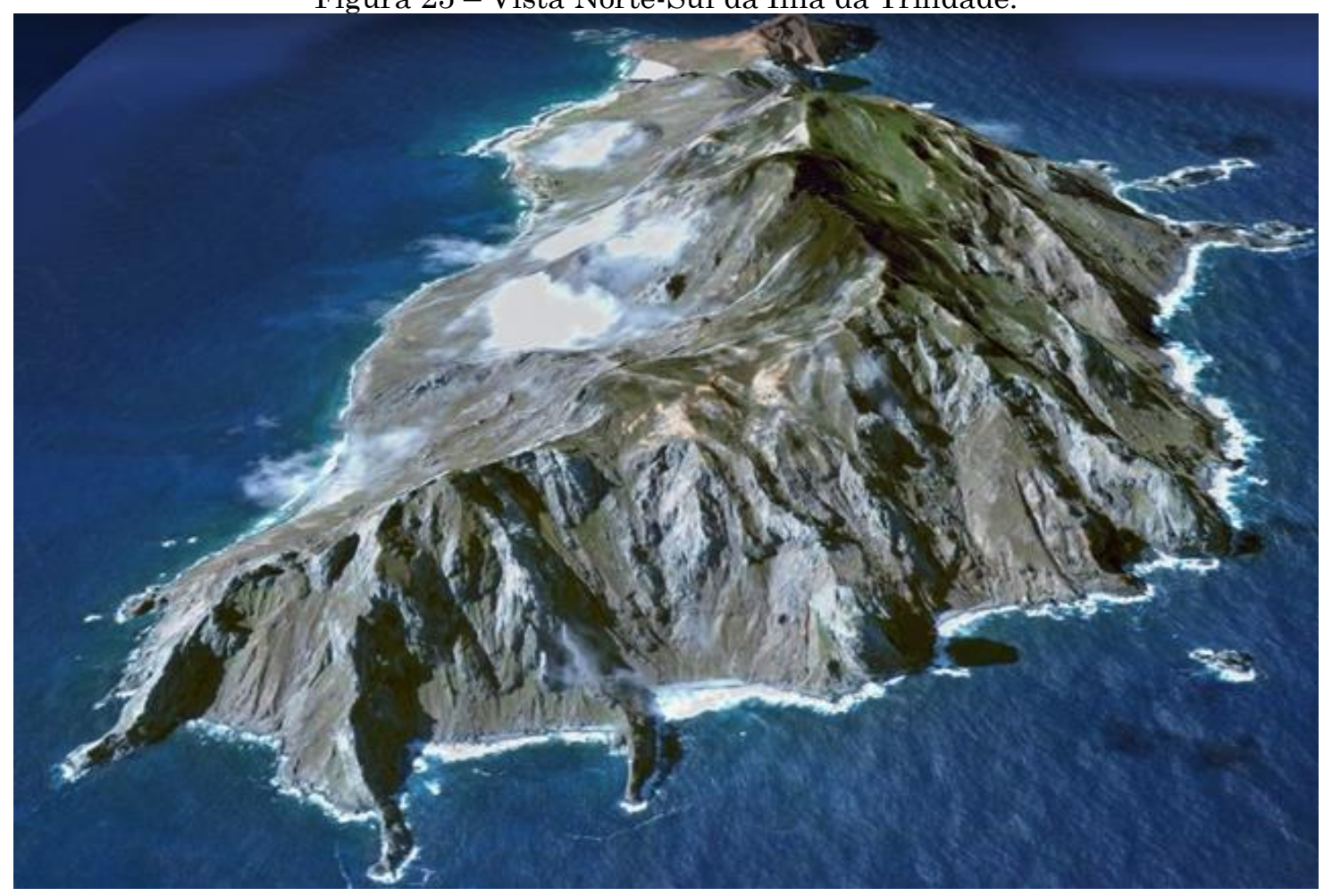

Fonte: Google Earth, 2019. 
Nas faces Sul e Sudoeste, pode-se verificar uma zona intermediária de ITU, quando comparada às anteriormente descritas, ocorrendo zonas de concentração associados aos Holllow e, de dispersão, associados a Cristas ou Picos, como destacado por Clemente et al. (2018) são pedoclimas mais frios e úmidos, além de possuir relevo mais escarpado.

As áreas de maior ITU corroboram para a presença de rios, tal como ao da bacia do Rio de Captação na porção Leste da ilha, onde se encontram as instalações dos habitantes.

\section{CONSIDERAÇÕES FINAIS}

As análises realizadas a partir dos mapas temáticos gerados neste trabalho, corroboram para verificar as relações entre a morfometria e a morfologia da ilha da Trindade e, associálas com a sua evolução ao longo do tempo, onde observou-se que a face leste possui uma maior morfogênese quando compara as demais.

A morfogênese mais elevada na porção leste da ilha da Trindade pode ser evidenciada pelos baixos valores de declividade indicando um relevo plano e suave ondulado e fator LS, em relação a porção Oeste, que possui altos valores percentuais de declividade apresentando relevo forte ondulado e montanhoso e de fator LS. Atribui-se a maior morfogênese do relevo na porção Leste da Ilha a ação das intemperes climáticas, mais proeminentes durante a maior parte do ano.

Em relação a classificação Geomophons, as vertentes da face leste são caracterizadas por muitas áreas côncavas, que são denominadas Escavado/Concavidade o que favorece a concentração de fluxo de água. A face oeste apresenta algumas zonas de convergências de fluxos de água, sendo de menor expressão do que encontradas na face leste, mas com maior amplitude altimétrica, sendo seu relevo muito escapado. $\mathrm{Na}$ face Noroeste as vertentes se apresentam escarpadas, mas com menor ocorrência de zonas de convergências de fluxos.

Os Índices Topográficos de Umidade, alto e muito alto são encontrados principalmente na porção Leste da Ilha da Trindade, associados a cabeceiras de drenagem em feições morfológicas denominadas de Escavado/Concavidade. Tais índices reforçam a maior disponibilidade de água na porção leste da ilha em relação as demais, fator importante para a sua evolução geomorfológica.

\section{AGRADECIMENTOS}

Agradecimentos ao Laboratório de Modelagens de Sistemas Ambientais (LAMOSA), a Próreitoria de Extensão da Ufes (Proex-Ufes), à Marinha do Brasil pela logística e todo apoio de seus militares, ao PROTRINDADE, à Secirm, à Capes pelo fornecimento de bolsas de estudos e ao Programa de Pós-Graduação em Geografia da Universidade Federal do Espirito Santo.

\section{REFERÊNCIAS}

ALMEIDA, F. F. M. Monografia XVII Geologia e Petrologia da Ilha da Trindade. Rio de 
Janeiro - RJ: Serviço Gráfico do Instituto Brasileiro de Geografia e Estatística - IBGE, 1962.

ALVES, R. J. V.; SILVA, N. G. Três Séculos de História Natural na Ilha da Trindade com Comentários Sobre Sua Conservação. [S.l.]: Smashwords, 2016. Ebook. ISBN 9781370853601. Available in: <https://bit.ly/2PN6Tp3>. Acessed: March 04, 2020.

ALVES, R. J. V. Ilha da Trindade \& Arquipélago Martin Vaz: Um Ensaio Geobotânico. Rio de Janeiro - RJ: Serviço de Documentação da Marinha. 24 v. 1998.

ANGULO, R. J. et al. Quaternary sealevel changes and coastal evolution of the Island of Trindade, Brazil. Journal of South American Earth Sciences, v. 84, n. April, p. 208-222, 2018.

https://doi.org/10.1016/j.jsames.2018.04.003 BARROS, L. L.; STEINKE, V. A. Análise morfométrica automatizada para bacia do rio Maranhão. In Simposio Brasileiro de Sensoriamento Remoto (SBSR), Anais. Natal, RN: INPE, 2009. v. XIV, p. 4655-4661, 2009.

BESKOW, $\mathrm{S}$ et al. Estimativa do escoamento superficial em uma bacia hidrográfica com base em modelagem dinâmica e distribuída. Revista Brasileira de Ciencia do Solo, v. 33, n. 1, p. 169-178, 2009. https://doi.org/10.1590/S010006832009000100018

BEVEN, K. J.; KIRKBY, M. J. A physically based, variable contributing area model of basin hydrology. Hydrological Sciences Bulletin, v. 24, n. $1, \quad$ p. $43 \quad$ - $69,1979$. https://doi.org/10.1080/02626667909491834

BRASIL. Decreto-Presidencial n 9.312 , de 19 de Março de 2018. Cria a Área de Proteção Ambiental do Arquipélago de Trindade e Martim Vaz e o Monumento Natural das Ilhas de Trindade e Martim Vaz e do Monte Columbia. Diário Oficial da União. Ed. 54. Seção 1. Página 1. Available: <http://www.in.gov.br/materia/-

/asset_publisher/Kujrw0TZC2Mb/content/id/7180 753/do1-2018-03-20-decreto-no-9-312-de-19-demarco-de-2018-7180749> Acessed: March 4, 2020.

BRASIL, Marinha do. Relatório Ambiental Simplificado. Rio de Janeiro: Diretoria de Hidrografia da Marinha, relatório interno, 09p. 2017.

CALLIARI, L. J. et al. Sandy Beaches of Brazilian Oceanic Islands. In: Short A., Klein A. (eds) Brazilian Beach Systems. Coastal Research Library, vol 17. Springer, Cham. p. 543 - 571. 2016. https://doi.org/10.1007/978-3319-30394-9_19
CARVAlHO, A. H. O.; CASTRO, F. S.; PENA, F. E. R. Caracterização Morfométrica da Bacia Hidrográfica do Córrego Santa Maria, Ibatiba ES. Nucleus, v. 11, n. 2, p. 317-324, 2014. https://doi.org/10.3738/1982.2278.1161

CASTRO, J. W. A. Ilhas oceânicas da Trindade e Fernando de Noronha, Brasil: Uma visão da Geologia Ambiental. Revista da Gestão Costeira Integrada, v. 10, n. 3, p. 303-319, 2010. https://doi.org/10.5894/rgci170

CLEMENTE, E. P.; SCHAEFER, C. E. R. G.; OLIVEIRA, F. S. Proposta de Zoneamento Ambiental para a Ilha da Trindade (ES). Boletim de Pesquisa e Desenvolvimento / Embrapa Solos, Ebook. ISSN 1678-0892. 2011. Available:

<https://ainfo.cnptia.embrapa.br/digital/bitstrea m/item/58010/1/bpd171-2011-ilha-trindade.pdf>. Acessed: March 4, 2020.

CLEMENTE, E. P. et al. Fracionamento da Matéria Orgânica dos Solos da Ilha da Trindade. Revista do Departamento de Geografia, v. 36, p. 48-62, 2018. https://doi.org/10.11606/rdg.v36i0.147796 CHRISTOFOLETTI, A. Análise morfométrica de bacias hidrográficas. Notícias Geomorfológicas, v. 18, n. 9, p. 35-64, 1969.

CORDANI, U.G. Idade do vulcanismo no Oceano Atlântico Sul. Boletim IGA, v. 1, p. 09-75, 1970. https://doi.org/10.11606/issn.2316-9001.v1i0p0975

DESMET, P. J. J.; GOVERS, G. A GIS procedure for automatically calculating the USLE LS factor on. Journal of Soil and Water Conservation, v. 51, n. 5, p. 427-433, 1996.

EMBRAPA - Empresa Brasileira De Pesquisa Agropecuária. Sistema Brasileiro de Classificação de Solos. 5 ed. Brasília, DF, 2018. Available: <https://www.embrapa.br/en/solos/sibcs>.

Acessed: March 4, 2020.

FERNANDEZ, O. V. Q. Caracterização Morfométrica das Bacias Urbanas e Periurbanas de Marechal Cândido Rondon, Paraná. Geografia em Questão, v. 09, n. 2, p. 88-106, 2016.

JASIEWICZ, J.; STEPINSKI, T. F. Geomorphons-a pattern recognition approach to classification and mapping of landforms. Geomorphology, v. 182, n. November, p. $147-$ 156 , 2013. http://dx.doi.org/10.1016/j.geomorph.2012.11.005 HORTON, R. E. Erosional development of streams and their drainage basin: hydrophysical approach to quantitative morphology. Bulletin of the Geological Society of America, v.56. p. 273 - 370. 1945. https://doi.org/10.1130/00167606(1945)56[275:EDOSAT]2.0.CO;2 
MACHADO, M. R. et al. Endemismo Pedológico e os Solos da Ilha da Trindade - Atlântico Sul, Brasil. Revista do Departamento de Geografia, v. 11, n. spe, p. 238 - 248, 2017. https://oi.org/10.11606/rdg.v0ispe.132762

MARQUES, C. P. M.; JUNIOR, A. P. M.; OLIVEIRA, F. S. Hidrogeomorfologia da Ilha da Trindade - Caracterização da Única Rede Hidrográfica Permanete nas Ilhas Oceânicas Brasileiras. In: PEREZ FILHO, A.; AMORIM R.R. (org). Os desafios da Geografia Física na Fronteira do Conhecimento. Ebook. ISBN 978-85-85369-16-3. Campinas - SP, Instituto de Geociências - UNICAMP, 2017. p. 6099-6111. https://doi.org/10.20396/sbgfa.v1i2017.2500

MOHR, L. V. et al. ILHAS OCEÂNICAS BRASILEIRAS: DA PESQUISA AO MANEJO

- volume II. v. 2. Brasília: MMA/Secretaria de Biodiversidade e Florestas, 2009.

MOURA, C. A. Avaliação de tendência a enchentes das bacias hidrográficas do município de caraguatatuba (SP). Revista de Geografia (UFPE), v. 30, n. 2, p. 6-17, 2013.

MURPHY, R. C. The Bird life of Trinidad Islet. Auk, v. XXXII, p. 332-348, 1915. https://doi.org/10.2307/4072683

PEDROSO, D.; PANISSET, J. S.; ABDO, L. B. B. Climatologia Da Ilha Da Trindade. In: Protrindade: Programa Pesquisa Científica na Ilha da Trindade 10 anos Pesquisas. $1^{\mathrm{a}}$ Ed. Brasília - DF: Secretaria da Comissão Interministerial para os Recursos do Mar, 2018. PIRES, G. L. C. et al. New ${ }^{40} \mathrm{Ar} /{ }^{39} \mathrm{Ar}$ ages and revised ${ }^{40} \mathrm{~K} / 40 \mathrm{Ar} *$ data from nepheliniticphonolitic volcanic successions of the Trindade Island (South Atlantic Ocean). Journal of Volcanology and Geothermal Research, v. 327, p. 531-538, 2016 http://dx.doi.org/10.1016/j.jvolgeores.2016.09.020 SÁ, M. M. F. Caracterização Ambiental, Classificação e Mapeamento dos Solos da Ilha Da Trindade, Atlântico Sul. Viçosa, MG Brasil. 2010. 65 f. Thesis (Master Degree in
Magister Scientiae) - Universidade Federal de Viçosa, Viçosa, 2010.

SANTOS, C. A.; SOBREIRA, F. G. Análise morfométrica como subsídio ao zoneamento territorial: o caso das bacias do Córrego Carioca, Córrego do Bação e Ribeirão Carioca na região do Alto Rio das Velhas-MG. Rem: Revista Escola de Minas, v. 61, n. 1, p. 77-85, 2008. https://doi.org/10.1590/S0370-

44672008000100013

SPANGHERO, P. E. S. F.; MELIANI, P. F.; MENDES, J. S. Mapeamento Hidrográfico de Detalhe e Análise Morfométrica Comparativa das Bacias dos Rios Tijuípe e Tijuipinho, Litoral Sul da Bahia. Caminhos de Geografia, v. 16, n. 53, p. 101-117, 2015.

STIPP, N. A. F.; CAMPOS, R. A.; CAVIGLIONE, J. H. Análise Morfométrica da Bacia Hidrográfica do Rio Taquara - Uma Contribuição para estudo das Ciências Ambientais. Portal da Cartografia, v. 3, n. 1, p. 105-124, 2010 .

STRAHLER, A. N. Hypsometric (area-altitude) analysis of erosional topography. Geological Society America Bulletin, v.63. p.1117-1142, 1952. https://doi.org/10.1130/00167606(1952)63[1117:HAAOET]2.0.CO;2

- Quantitative analysis of watershed Geomorphology. Transaction of American Geophysics Union, v.38. p.913-920, 1957. https://doi.org/10.1029/TR038i006p00913

TORRES, J. L. R. et al. Análise das caracteristicas quantitativas e qualitativas da microbacia do córrego barreiro, afluente do Rio Uberaba. Revista Árvore, v. 35, n. 4, p. 931939, 2011. https://doi.org/10.1590/S010067622011000500018

UMETSU, R K et al. Morphometric and socioenvironmental analysis of an Amazonian watershed, Carlinda, MT, Brazil. Revista Arvore, v. 36, n. 1, p. 83-92, 2012. https://doi.org/10.1590/S0100-

67622012000100010 